\title{
SOIL INOCULATION WITH AZOTOBACTER
}

BY

PAUL EMERSON

A DISSERTATION SUBMITTED TO THE GRADUATE FACULTY OF THE IOWA STATE COLLEGE OF AGRICULTURE AND MECHANIC ARTS IN PARTIAL FULFILLMENT OF THE REQUIREMENTS FOR THE DEGREE OF DOCTOR OF PHILOSOPHY

NO. 3

REPRINTED FROM RESEARCH BULLETIN No. 45 IOWA AGRICULTURAL EXPERIMENT STATION 



\title{
Soil Inoculation with Azotobacter
}

\author{
By PAUL EMERSON \\ AGRICULTURAL EXPERIMENT STATION \\ IOWA STATE COLLEGE OF AGRICULTURE \\ AND MECHANIC ARTS \\ AGRONOMY SECTION \\ Soil Bacteriology
}

AMES; IOWA 


\section{IOWA AGRICULTURAL EXPERINENT STATION OFFICERS AND STAFF}

Raymond A. Pearson, M. S. A.. LL. D.. President C. F. Curtiss, M "S. A., D. S., Director

W. H. Stevenson. A. B.. B. S. A., Vice-Director AGRICULTURAL ENGINEERING

C. K. Shedd, B. S. A., B. S. in A. E., W. A. Foster, B. S. in Ed., B. Arch., Acting Chief AGRONOMY

W. H. Stevenson, A. B., B. S. A., Chief George E. Corson, B. S., M. S., As-

H. D. Hughes, B. S., M. S. A., Chief in Farm Crops

P. E. Brown, B. S., A. M.. Ph. D., Chief in Soil Chemistry and Bacteriology

L. C. Burnett. M. S. A., M. S., Chief in Cereal Breeding

L. W. Forman. B. S. A., M. S., Chief in Field Experiments

John Buchanan, B. S. A., Superintendent of Co-operative Fxperiments

R S Potter A B M. S. Ph. D. Assistant Chief in Soil Chemistry

$R$ C Srvder. B. S., Assistant in Soil Chamistry

H. W. Johnenn. B S., M. S. Assistant in Soils (absent on leava)

W. H. Pew. B. S. A., Chief

ANIMAL HUSBANDRY

J. M. Evvard. M. S. Assistant Chief in Animal Husbandry and Chief in S'wine Production

R. Dunn, B. S., Assistant in Animal Husbandry

H. A. Bittenbender, B. S. A., Chief in Poultry Husbandry

\section{BACTERIOLOGX}

R. E. Buchanan, B. S., Ph. D., Chief : Associate in Dairy and Soil Bacteriology BOTANY

L. H. Pammel, B. Agr., M. S., Ph. D., I. E. Melhus, Ph. D., Chief in Plant Chief Pathology

Charlotte M. King. Assistant Chief in Bctany CHEMISTRY

A. W. Dox, B. S.. A. M., Ph. D., Chief S. B. Kuzirian, A. B., A. M., Ph. D., (absent on leave)

TV G. Gaessler, B. S., Acting Chief

A. R. Lamb, B. S., M. S.. Assistant Assistant

G. W. Roark, Jr., B. S., Assistant

DAIRYING

Lester Yoder, B.'S., M. S., Assistant

M. Mortensen, B. S. A., Chief

D. E. Bailey, B. S., Assistant Chief

B. W. Hammer, B. S.' A., Chief in Dairy Bacteriology

R. L. Webster, A. B., Acting Chief Wallace Park, B. S., Assistant in Agriculture

TARM MANAGEMENT

$\begin{array}{ll}\text { H. B. Munger, B. S., Chief } & \text { O. G. Lloyd, B. S., M. S', Assist. Chief }\end{array}$ HORTICULTURE AND FORESTRY

S. A. Beach, B. S.. M. S., Chief

T. J. Maney, B. S., Chief in Pomolog'y'

Harvey L. Lantz, B. S., Assistant in Fruit Breeding

W. E. Whitehouse, B. S., Assistant in Pomology

Andrew Edward Murneek, B. A., Research Fellow in Pomology

\section{RURAL SOCIOLOGY}

J. B. Kendrick, B. A., Research Assistant in Pomology

A. 'I. Erwin, M. S., Chief in Truck Crops

Rudolph A. Rudnick, B. S., Assistant in Truck Crops

G. B. McDonald, B. S. F., M. F., Chief in Forestry

Frank H. Culley, B. S. A., M. L. A., Chief in Landscape Architecture

G. H. Von Tungeln, Ph. B., M. A., Chief

VETERINARY MEDICINE

C. H. Stange, D. V. M., Chief GENERAT, OFFICERS

F. W. Beckman, Ph. B. Bulletin Editor F. E. Colburn, Photographer Gretta Smith. A. B. Assistant to Bulletin Editor C. E. Brashear, B. S. A., Assistant to Director

LIBRARY OF COMGRESS 


\title{
Soil Inoculation With Azotobacter*
}

\author{
BY PAUL EMERSON.
}

Following the discovery of the nitrogen fixing powers of the symbiotic bacteria in the soil, early investigators found that the power of utilizing the free atmospheric nitrogen was not confined to the symbiotic bacteria alone. They noted increases in soils which had borne no legumes and they found that fallow soils in particular increased appreciably in nitrogen content. These facts stimulated researches which led to the discovery of many forms of bacteria which are able, when growing alone, to fix nitrogen from the air. The chief of these is now known as the azotobacter group.

It seems likely that the azotobacter will prove more effective in fixing nitrogen than the symbiotic bacteria, although the general requirements of the two classes of organisms are very similar. The azotobacter are active in practically all soils regardless of the kind of erop grown when conditions for their growth are satisfactory. These conditions are probably much the same as for the symbiotic bacteria except that these latter organisms require the presence of a specific legume for fixing the greatest amount of nitrogen. Azotobacter require a certain amount of carbonaceous material in the soils and are usually stimulated by a small amount of nitrogen, but the exact optimum conditions for their growth are as yet unknown. These organisms are active in causing nitrogen increases in many soils, but the feasibility of introducing them into the soil or of attempting to increase their ziitrogen-fixing powers by artificial means, and the effect of the presence of growing plants on their efficiency are questions as yet unanswered, although Lipman has indicated that under proper conditions successful inoculation may be accomplished in soils and Bottomley has successfully grown pure cultures of these organisms in the presence of growing plants with favorable results.

\section{HISTORICAL}

Beijerinck (2) isolated and described the first azotobacter (in 1901). He found two species, one of which he named Azotobacter chroöcoccum and the other Azotobacter agilis. The former was isolated from the soil and the latter from a sample of water taken from one of the canals in the city of Delft. Two years later Lipman (36) added a third species, A. vinelandii, to the list and the following year isolated and described two more, giving them the names of $A$. beijerinckii and $A$. woodstownii. Of the five organisms of this species, $A$. chroöcoccum, $A$. beijerinckii

*Thesis submitted in partial fulfilment of the requirements for the Degree of Doctor of Philosophy at the Iowa State College. 
and $A$. vinelandii are considered the most important in soil inoculation studies.

The frequeney with which investigators in all parts of Europe and America have isolated azotobacter from various soils, indicates that they are widely distributed. Christensen (10) found that they were present throughout northwestern Europe, the activity of the organism apparently depending on the basicity of the soil. This view was later supported by the works of Fisher (14), Löhnis and Pillai (45) and others. Ashby (1) studied the soils of Mombasa, East Africa, Cairo, Egypt and Rothamsted, England and found azotobacter forms present in most eases. Lipman and Burgess (42) working with forty-six samples of soil from various parts of the world, found that over one-third of them contained azotobacter, the predominant form being $A$. chroöcoccum. Many of the soils examined were museum specimens and had been kept in tightly stoppered bottles for long periods of time.

\section{DESCRIPTION OF AZOTOBACTER.}

Beijerinck characterizes the azotobacter as stout bacteria, 4-6 microns or less in length, sometimes longer, occurring as large diplococei or short rods in young cultures, the hyaline cells often containing a vacuole and the entire organism enclosed in a mucilagenous wall of varying thickness. They have a single polar flagellum or bundles of 4-10 polar flagella of about the same length as the organism itself. Beijerinck found no spores. Vagler (65) writes that the older colonies produce involution forms similar to those of yeasts while Heinz (22) and Fisher (15) showed that the organisms can resist drying for six to nine months. Later investigations by Mulvania (50) and Löhnis and Smith (47) demonstrated that the organism produces spores and completes a very complicated life cycle. Descriptions of azotobacter and detailed cultural characteristics of the organism were given by Lipman (35), Beijerinck (2), Prazmowski (54), Warmbold (70), Bonazzi (6), Löhnis and Westerman (48), Löhnis and Hanzawa (44), Jones (27) and others.

\section{ACTIVITIES OF AZOTOBACTER.}

Beijerinck first claimed that the isolated pure cultures of azotobacter were able to fix the atmospheric nitrogen in appreciable amounts; later, however, when working with Van Delden (4), he retracted this statement, claiming that pure cultures did not have this ability and that only in the presence of very small celled organisms called radiobacter could the free nitrogen of the air be fixed in the soil. Gerlach and Vogel (18), Heinz (23), Lipman (37) and Freudenreich (17) proved conclusively that the earlier conclusions of Beijerinck were correct and that 
the organism may fix considerable amounts of nitrogen in pure cultures. Lipman accounts for the fact that Beijerinck did not get a fixation of nitrogen in pure cultures by showing that the organism will not fix nitrogen unless the reaction of the medium is made neutral or slightly alkaline. When Beijerinck later accepted this suggestion he found that his pure cultures were able to fix atmospheric nitrogen.

\section{STUDIES OF AZOTOBACTER.}

Very few investigators have attempted to inoculate soils with azotobacter or other non-symbiotic nitrogen fixing bacteria under conditions approximating those in the field. The influence of various kinds of sugars, cellulose, inorganic salts, and various organic compounds on the nitrogen-fixing power of the organisms have been studied extensively. Gerlach and Vogel (19), Pringsheim (55), Krainsky (33), Koch (30), Hoffman and Hammer (25) and Stranak (61) have found that various sugars and cellulose materially increase their nitrogen fixing powers while Fisher (16), Christensen (10), Löhnis and Pillai (46), Wilfarth and Wimmer (59) Kaserer (28), Rosing (59), Vogel (66), Greaves and Anderson (20) and Pringsheim (56) have shown that small amounts of lime, very small amounts of nitrogen, various inorganic salts and even a very small amount of arsenic will stimulate the nitrogen fixing power of the organisms in the presence of certain carbon compounds. Stoklasa (60) studied the products of the activities of the azotobacter organisms, confining his researches largely to the amounts and kinds of gases produced under different circumstances, under the influence of various substances supposed to be energy sources, and under varying temperature conditions. His results have been more or less confirmed by the works of Thiele (64), Hoffman (24), Kellerman and Smith (29) and Ehrenberg (13).

The activity of the azotobacter in soils in general, and particularly under laboratory conditions, was fully shown by the works of Lipman (39), Voorhees and Lipman (68), Löhnis (43), Kuhn (34), Freudenreich (17), Dvorak (12), Remy (57), Remy and Rosing (58), Jacobitz (26), Stranak (62), Headden (21), Peterson and Mohr (52), Koch and Seydel (31), Omeliansky and Ssewerowa (51), Warmbold (71) and others who demonstrated that under various conditions and in almost every type of known soil these organisms are able to fix appreciable amounts of the free atmospheric nitrogen. Only a few of these investigators, however, have made any attempt to secure an active flora of these organisms in the soil. Vogel (67) inoculated pure cultures of azotobacter into soils that had been treated with grape sugar, in some cases adding comparatively large amounts of nitrate of soda. In pot experiments with oats and mustard, increases were 
noted for the inoculated series, altho the pots receiving nitrate of soda gave the greatest yields. When the experiment was repeated in the field the inoculated plots gave smaller yields than the uninoculated, and the inoculation appeared to have an injurious effect upon the crop.

A short time later Lipman and Brown (41) tried inoculation experiments with $A$. vinelandii and $A$. beijerinckii. They sunk four foot cylinders open at both ends into the soil, filled the cylinders with soil and inoculated the soil with the organisms. The first summer the soils were left bare and then a rotation of crops was followed and oats, corn and rye grown in succession. While considerable variation was found in the nitrogen content of the crops and in the dry weight, the general conclusion reached was that the activities of the organisms did not increase the nitrogen content of the soil. The results do not preclude the possibility that inoculation with the organisms in question may be made of practical value, provided proper conditions for the best growth of the organisms are secured. Bottomley (7) and Bottomley and Hall (9) experimented with oats, barley and some root crops, and arrived at the same conclusions as did Lipman and Brown. Stranak (63) also inoculated soils with azotobacter and found a pronounced increase in the growth of potatoes, grain and beets.

Altho the experiments dealing with the inceulation of soils with azotobacter have been inconclusive, it is believed that under proper conditions such inoeulation may be extremely profitable.

\section{EXPERIMENTAL}

The wide distribution of non-symbiotic nitrogen fixing bacteria in many types of soils is practically parallel with the distribution of the symbiotic organisms, and since it is practical and profitable to inoeulate soil with the latter, even tho the particular organism may be present, the following questions quite naturally arise:

1. If the azotobacter are not present in the soil, can inoculation be profitably accomplished?

2. What soil conditions are necessary for the greatest fixation of nitrogen by these organisms?

These questions have an important bearing on the problem of the maintenance of permanent fertility in soils from the nitrogen standpoint and may govern the choice of the proper method of farming. Some commercial concerns have placed cultures on the market, claiming that they contain sufficient numbers of the nonsymbiotic nitrogen fixing bacteria to enable the farmer to solve his nitrogen problem without growing legumes. However, results of experiments showing that such cultures are capable of inoculating the soil were not found in the present investigation. 


\section{INCREASING THE NITROGEN FIXING POWER OF PURE CULTURES.}

Very little work has been done along the line of breeding pure cultures of bacteria to an increased efficiency in their specific actions, in fact, practically all the experiments have been carried out with the idea of finding a method whereby the organism could be kept alive for long periods without periodic transfers. The earliest investigation along this line was that of Czaplewski (11) who limited the amount of air in the tube by saturating the plug with paraffine. Later Lunt (49) found that certain cultures of water bacteria may be kept alive much longer in sterile water than in ordinary culture media. In some cases he kept certain organisms alive for two years by this method. Bolley (5) secured good growths of $B$. amylovorus and Bact. dianthi in agar and in bouillon by making transfers from cultures that had been hermetically sealed for nine years. It is not stated whether or not the organisms were tested for their pathogenicity and hence their virulence is left in doubt. This work supports that of Czaplewski in showing that cultures can be kept alive for long periods of time if the transpiration is reduced to a minimum. Some commercial concerns claim that they are able to increase the efficiency of their particular cultures of legume bacteria by alternate inoculations first on agar, then into sterile greenhouse soil, growing the specific legume to which the organism in question is adapted, and re-isolating the organism from the nodules produced on the roots of the legume. If this is possible for the symbiotic bacteria then it seems probable in the case of the nonsymbiotic organisms. The following questions naturally suggest themselves:

1. Can the nitrogen fixing power of azotobacter be increased by periodic transfers on nitrogen free media?

2. Can the nitrogen fixing powers of azotobacter be increased by growing the organism in the presence of growing plants?

In outlining work to answer the above questions it was realized that a large number of bacteria should be used. A number of large celled nitrogen fixing organisms that had all the staining reactions of the azotobacter type and closely resembled it in size and shape, were isolated in pure eultures from soil secured from the humus plots at the Iowa station and were designated with laboratory numbers. At the same time pure cultures were secured and their activities determined along with those of the unnamed eultures. The pure cultures were kindly furnished by Dr. J. G. Lipman of the New Jersey Agricultural Experiment Station and also by the American Museum of Natural History of New York. 


\section{MEDIA USED.}

The nitrogen free medium used thruout the experimental work was a modification of that proposed and used by Lipman (35), and its composition was as follows:

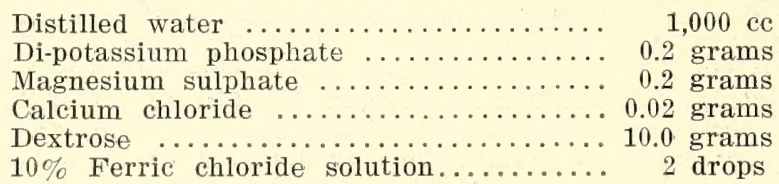

The solution was brought to boiling and made neutral to phenolphthalein by the addition of $\mathrm{N} / 10 \mathrm{NaOH}$. If a solid medium was desired $1 \%$ powdered agar was added. Sterilization was accomplished by placing in the autoclave at ten pounds for 20 minntes.

Inoculation was secured by seraping off a two days' growth from the agar slants with a sterile needle and transferring it to flasks containing $50 \mathrm{ec}$ of the above soluticn. In orcier to determine whether the nitrogen fixing power of the organisms was stimulated by the addition of nitrogen, the above solution with the addition of $1 \mathrm{mg}$. of nitrogen as sodium nitrate was used.

\section{PRELIMINARY STUDIES.}

All of the organisms of the azotobacter type including both the pure cultures and the unnamed cultures, were inoculated into $50 \mathrm{c}$. c. of both of the above solutions and tested for their nitrogen fixing powers. The inoculated solutions were incubated for three weeks at room temperature $\left(22-25^{\circ} \mathrm{C}\right)$ and then Ijeldahlized. The amount of nitrogen fixed by each organism in the different solutions is shown in table I. The same cultures were transferred 12 times at three to four day intervals on nitrogen tree media and their nitrogen fixing power tested in solutions with and without nitrogen. The results appear in table II.

The laboratory organisms used in table I had been freshly isolated and purified from the soil, the named cultures had been kept on agar slants for varying periods of time. During the time that the inoculated culture solutions were incubating the transfers were being made in preparation for the inoculations for table II.

Comparing the two tables we find that a majority of the organisms decreased in their ability to fix atmospheric nitrogen, altho a few showed a slight increase or at least retained their eíficiency. From these the following eight were selected for further study: No. 4, No. 22, No. 26, No 27, A. vinelandii, A. chroococcum, A. beijerinckii and $A$. chroococcum (HCM). These eight organisms were studied under both laboratory and greenhouse conditions. 
TABLE I-NITROGEN-FIXATION BBY PURE CULIURES IN SOLUTION WITH AND WITHOUT NITROGEN.

\begin{tabular}{|c|c|c|}
\hline \multirow[b]{2}{*}{ Organism } & \multicolumn{2}{|c|}{ N. Fixed in Mgs. } \\
\hline & 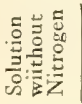 & 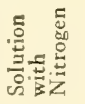 \\
\hline Lab. No. & 2.24 & $\theta .14$ \\
\hline Lab. No. & 2.38 & $1.5 t$ \\
\hline Lab. No. & 0.28 & $\ldots$ \\
\hline Lab. No. 4 & 0.98 & 1.96 \\
\hline Lab. No. & 1.96 & 1.82 \\
\hline Lab. No. 7 & 3.22 & 1.68 \\
\hline Lab. No. & 0.42 & 2.10 \\
\hline Lab. No. $10 \ldots$ & 0.42 & 0.81 \\
\hline Lab. No. 11 & 0.42 & 0.70 \\
\hline Lab. No. 12 & lost & 1.40 \\
\hline Lab. No. 14 & 1.12 & lost \\
\hline Lab. No. 15 & 2.80 & 1.12 \\
\hline Lab. No. $16 \ldots$ & 7.14 & lost \\
\hline Lab. No. 18 & $0.2 S$ & v. 48 \\
\hline Lab. No. 19 & 1.12 & 1.54 \\
\hline Lab. No. 20 & 0.56 & 1.96 \\
\hline Lab. No. 21 & 0.56 & 2.10 \\
\hline Lab. No. 22 & 0.42 & 2.52 \\
\hline Lab. No. 23 & 0.70 & 2.52 \\
\hline Lab. No. 24 & 0.70 & 1.82 \\
\hline Lab. No. $25 \ldots$ & 0.28 & 1.82 \\
\hline Lab. No. 26 & 0.56 & 2.10 \\
\hline Lab: No. 27 & 1.12 & 5.60 \\
\hline A. vinelandii _....... & lost & 2.66 \\
\hline A. chroococcuon (HCM) & 4.20 & 3.08 \\
\hline A. chroococcum & $0: 84$ & 1.54 \\
\hline A. chroococcum (Colo)- & 0.70 & 2.52 \\
\hline A. beijerinckii & $0: 81$ & 1.68 \\
\hline A. beijerinckii No: 5 & 1.96 & 2.38 \\
\hline
\end{tabular}

TABILE II-NLTROGEN-FTXATION BY PURE RULITURES IN SOLUTION WITH AND WITHOUT NITYROGEN.

After each organism has been transfer red twelve times on nitrogen-free media at three to four day intervals.

\begin{tabular}{|c|c|c|}
\hline \multirow[b]{2}{*}{ Organism } & \multicolumn{2}{|c|}{ N. Fixed in Mgs } \\
\hline & 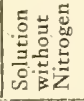 & 总 \\
\hline Lab. No. I. & 0.84 & 1.12 \\
\hline Lab. No. 2 & 0.14 & 0.00 \\
\hline Lab. No. & 0.14 & 0.98 \\
\hline Lab. No. 4 & 1.82 & 0.98 \\
\hline Lab. No. 6_- & 0.00 & 0.84 \\
\hline Lab. No. 7 & 0.28 & 0.28 \\
\hline Lab. No. $9_{-}$ & 0.00 & 1.26 \\
\hline Lab. No. 10 & 0.98 & 0.00 \\
\hline Lab. No. 11. & 0.00 & 1.68 \\
\hline Lab. No. 12. & 0.00 & 0.28 \\
\hline Lab: No: 14 & 0.42 & 1.12 \\
\hline Lab. No. 15 & 0.00 & 1.40 \\
\hline Lab. No. 16 & 0.00 & 0.14 \\
\hline Iab. No. 18 & 0.00 & 0.42 \\
\hline Lab. No. 19_- & 0.00 & 0.42 \\
\hline Lab. No. 20 & 0.98 & 1.54 \\
\hline Lab. No. 21 & 0.42 & 0.84 \\
\hline Lab. No. 22 & 2.52 & 1.12 \\
\hline 1.ab. No. 23 & 2.10 & 1.54 \\
\hline Lab. No. 24 & 0.00 & 1.68 \\
\hline Lab. No. 25 & 0.00 & 0.28 \\
\hline Lab. No. 26_ & 1.12 & 1.82 \\
\hline Lab. No. $27 \ldots$ & 1.40 & 2.52 \\
\hline A. vinelandii -... & 0.00 & 0.00 \\
\hline A. chroococeum - & 1.12 & 1.82 \\
\hline A. chrooeoceum (HCMI) & 2.52 & 1.12 \\
\hline A. chroocoecum (Colo) & 0.00 & 1.26 \\
\hline A. beijerinckii - & 0.42 & 2.52 \\
\hline A, beijerinckii No. 5 & 1.12 & 0.00 \\
\hline
\end{tabular}

\section{LABORATORY STUDIES.}

The laboratory studies were arranged in a series of three experiments as follows:

1. To determine the effect of transfers made every other day on the nitrogen fixing power of the organisms.

2. To determine the effect of transfers made once each week in sand cultures variously modified.

3. To determine the effect of growing four of the organisms on both agar and sand in large flasks with and without the presence of growing plants. 


\section{Series 1. To Determine the Effect of Transfers Made Every Other Day on the Nitrogen Fixing Power of \\ the Organisms.}

Using the eight selected organisms transfers were made every other day on the nitrogen free medium for a pericd of three weeks. It was feared that such rapid transferring for so long a period on a medium practically free from nitrogen would reduce the vitality of the organisms, aceordingly each fifth transfer was made on a modification of the medium consisting in the addition of one milligram of nitrogen as sodium nitrate to each liter of the regular dextrose agar. At the end of the transfer period the organisms were inoculated into the nitrogen free and nitrogen containing solutions incubated for the same periods of time and the amount of nitrogen fixed determined by Kjeldahlizing. The results of the determinations are shown in table III.

'INABLE ITI-THE EFFEOT' OF 'TRANSFERS MADE" EVERY OTHER DAT FOR FOUR WEEKS ON THE NITYROGEN FIXING POWER OF" THE ORGANISMS.

\begin{tabular}{|c|c|c|c|c|c|c|}
\hline \multirow{2}{*}{ Organism } & \multicolumn{6}{|c|}{ Nitrogen Fixed in Mgs. } \\
\hline & \multicolumn{3}{|c|}{$\begin{array}{c}\text { Solution without } \\
\text { Nitrogen }\end{array}$} & \multicolumn{3}{|c|}{$\begin{array}{l}\text { Solution with } \\
\text { Nitrogen }\end{array}$} \\
\hline & (a) & (b) & $(A v)$. & (a) & (b) & $\left(A v^{*}\right)$ \\
\hline Lab. No. 4 & 0.14 & 0.42 & 0.28 & 0.70 & 0.42 & 0.56 \\
\hline Lab. No. 22 & 0.00 & 0.00 & 0.00 & 0.14 & 0.56 & 0.35 \\
\hline Lab. No. 26 & $0.1 t$ & 0.14 & 0.14 & 0.28 & 0.98 & 0.63 \\
\hline Lab. No. 27 & 0.38 & 3.50 & 1.98 & 0.70 & 0.98 & 0.84 \\
\hline A. vinelandii -- & 0.28 & 0.42 & 0.35 & 0.98 & 0.98 & 0.98 \\
\hline A. chroococcum & 053 & 0.28 & 0.42 & 0.95 & 1.12 & 1.05 \\
\hline A. chroococcum (HCM) & 2.66 & lost & 2.665 & 1.40 & 1.40 & 1.40 \\
\hline A. beijerinekii & 0.84 & $2.66^{\circ}$ & 1.75 & 0.28 & 0.28 & 0.28 \\
\hline
\end{tabular}

That these transfers should have been made at longer intervals is evidenced by the fact that tables I and II showed that 12 of the cultures had increased in efficiency after they had been transferred cvery three days for 36 days. However, during the latter work the organisms did not show any indications of a loss of vitaiity and the growth at all times was vigorous and rapid. Table III shows a decrease in the nitrogen fixing powers of all the organisms except in the case of A. chroococeum (HCM) which appears to have retained its efficiency thruout the experiment.

\section{Series 2. To Determine the Effect on the Nitrogen Fixing Power of Transfers Made Each Week in Sand Cultures.}

In the following experiment sand was used instead of ayar as the basis for the medium. Ground oats straw, ground red elover hay and either the regular dextrose solution, or the dextrose solution containing nitrogen were added. The tests were earried out in tubes arranged as follows: 
$6.25 \mathrm{gr}$. sand +2.5 ce $\mathrm{N}$. free dextrose solution.

$6.25 \mathrm{gr}$. sand +2.5 ce dextrose solution containing 0.2 gr. $\mathrm{NaN}_{3}$ per liter.

$6.25 \mathrm{gr}$. sand +3.5 ce $\mathrm{N}$. free dextrose solution $+0.1 \mathrm{gr}$. clover nay.

6.25 gr. sand +3.5 ce $\mathrm{N}$. free dextrose solution $+0.1 \mathrm{gr}$. oats straw.

The organisms were transferred directly from the slants intc the tubes and there allowed to incubate at room temperature for seven days. A small portion of the sand was then transferred to a fresh tube of the same medium as the original. As this particular experiment did not directly follow the others the efficiency of the organisms was tested before they were inoculated into the sand. Table IV shows the amount of nitrogen fixed by the pure

TABLE IV-THE! NITROGEN FIXING POWVER OF THE PURE CULTURES TMMEDLATELY BEFIORE THE SAND CULTURE EXPEIRIMENTS.

\begin{tabular}{|c|c|c|c|c|c|c|}
\hline \multirow[t]{2}{*}{ Organism } & \multicolumn{3}{|c|}{$\begin{array}{c}\text { Solution witnout } \\
\text { Nitrogen }\end{array}$} & \multicolumn{3}{|c|}{$\begin{array}{c}\text { Solution with } \\
\text { Nitrogen }\end{array}$} \\
\hline & (a) & (b) & (Av.) & (a) & (b) & Av. \\
\hline Lab. No. 4 & 0.14 & 0.70 & 0.42 & 0.28 & $1.5 t$ & 0.91 \\
\hline Lab. No. 22 & 0.00 & 0.00 & 0.00 & 3.36 & $3.0 \mathrm{~s}$ & 3.22 \\
\hline Iab. No. 26 & 0.00 & 0.14 & 0.07 & 2.94 & 2.66 & 2.80 \\
\hline Lab. No. 27 & 0.00 & 0.00 & 0.00 & 2.38 & 2.52 & 2.45 \\
\hline A. vinolandii . & 0.00 & 0.00 & 0.00 & 1.40 & 1.40 & 1.40 \\
\hline A. chroococcum - & 0.00 & 0.11 & 0.07 & 2.80 & 2.66 & 2.73 \\
\hline A. chroococeum ( $\mathrm{HC} \mathrm{I})$ & 0.00 & 0.00 & 0.00 & 2.52 & 2.38 & 2.45 \\
\hline A. beijerinckii & 0.98 & 0.84 & 0.91 & 2.94 & lost & 2.94 \\
\hline
\end{tabular}

cultures at the beginning of this series of incubation, and the same methods as in the previous experiments.

At the end of the fourth transfer period, i. e., four weeks after the start of the experimental series, the organisms were inoculated into dextrose solution and their nitrogen fixing powers determined. After four more weeks of transferring or in all eight weeks the final inoculation into dextrose solution was made. The influence of the oats and clover in the presence of sand on the nitrogen fixing power of the organisms used is shown in tables $\mathrm{V}$ and VI, by the fact that both the large celled organisms of the

TABLE V.-NTTROGEN FIXED BY THE PURE CULTURES AFTER FOUR TRANSFERS IN SAND AT PERIODS OF SEVEN DAYS EACH.

\begin{tabular}{|c|c|c|c|c|}
\hline \multirow{2}{*}{ Organism } & \multicolumn{4}{|c|}{ Nitrogen Fixed in Mgs. } \\
\hline & dex. sol. & $\begin{array}{c}\text { dex. sol. } \\
+\mathrm{N}\end{array}$ & $\begin{array}{l}\text { dex. sol.t } \\
\text { oats straw }\end{array}$ & $\begin{array}{l}\text { dex. sol.t } \\
\text { clover hay }\end{array}$ \\
\hline Lab. No. 4 & 0.28 & 0.35 & 0.28 & 0.98 \\
\hline 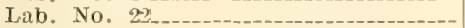 & 0.07 & 0.28 & 0.00 & 0.35 \\
\hline Lab. No. 26 & 0.77 & 0.07 & 0.14 & 0.00 \\
\hline Iab. No, 27 & 0.42 & 0.35 & 1.27 & 0.42 \\
\hline A. vinelandii an & 0.14 & 0.21 & 0.42 & 0.28 \\
\hline A. ehroococeum & 0.21 & 0.21 & 0.07 & 0.21 \\
\hline A. ehroococeum (HCM) & 0.07 & 0.14 & 1.19 & 0.42 \\
\hline A. beijerinckii _......... & 0.14 & 0.28 & 0.35 & 0.28 \\
\hline
\end{tabular}


TIBLE VI-NITROGEN FIXED BY THE PURE CULTURES AFTER EIGHT TYRIANSFERIS A'T' PERLIODS OF SEVEN DAYS EACH.

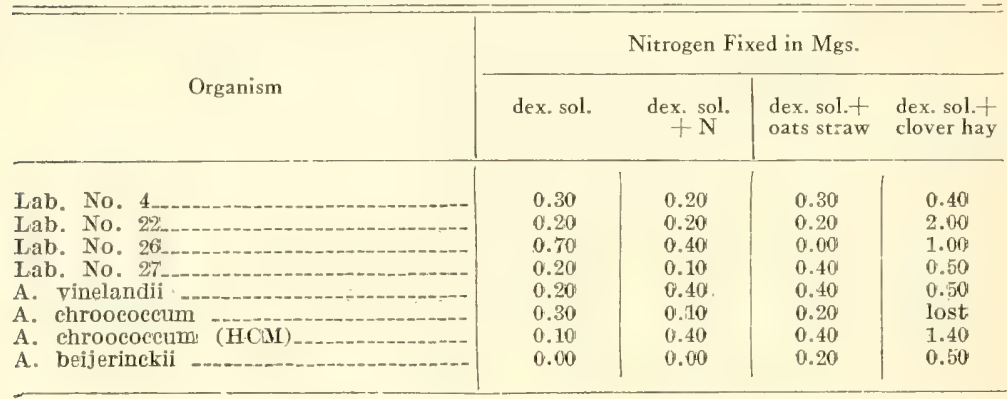

azotobacter type and the azotobacter themselves, made gains in their nitrogen fixing powers. There was no distinct gain due to any one kind of carbonaceous material. Of the six organisms showing gains $A$. chroococcum made the most notable, especially in the presence of the oats straw. The nitrogen fixing power of No. 4 appears to be rather constant thruout the series, with no appreciable gain or loss. A. beijerinckii showed a decided loss in its power to fix nitrogen in each of the four media, but gave a slight indication that in the presence of the clover hay it might be slowly regaining its power.

Series 3. To Determine the Effect of Growing the Organisms on Both Agar and Sand With and Without the Presence of Growing Plants.

The main points considered in this experiment were: An increase in the surface area over which the organism could grow; an increase in the time between transfers and the growing of the organisms in the presence of an undetermined species of algæ and with growing oats and red elover plants. Two liter Erlenmeyer flasks were used and arranged in the following manner conforming to the outlines of the experiment:

Flask No. 1. $1000 \mathrm{cc}$ N. free dex. agar +1 gr. $\mathrm{CaCO}_{3}$ planted to oats.

Flask No. 2. 1000 ce N. free dex. agar +1 gr. CaCO 3 planted to red clover.

Flask No. 3. 1000 ec N. free dex. agar+1 gr. $\mathrm{CaCO}_{3}$ planted with an undetermined species of algæ.

Flask No. 4. $1000 \mathrm{gr}$. pure quartz sand $+180 \mathrm{cc} \mathrm{N}$. free dex. solution neutralized with $\mathrm{CaCO}_{3}$, planted with oats.

Flask No. 5. 1000 gr. pure quartz sand +180 cc N. free dex. solution neutralized with $\mathrm{CaCO}_{3}$, planted with red clover.

Flask No. 6. 1000 gr. purel quartz sand $+180 \mathrm{cc}$ solution without dex. neutralized with $\mathrm{CaCO}_{3}$; planted with an undetermined species of algæ.

Check flasks of sand and dextrose agar. 
The flasks of agar were sterilized in the autoclave at ten pounds for 30 minutes, but the flasks of sand were sterilized at 15 pounds pressure for four hours once a day for three consecutive days. Bacteriological tests on the sand at the end of that time showed it to be sterile.

The culture of the algae used was so closely associated with a bacterial growth that a separation would have required a long time. For that reason it was not purified but was grown in sterile distilled water, for about three months before inoculation. The inoculation of the algae was made in the flasks about two weeks before the inoculation with the azotobacter eulitures in order that the algae might make a sufficient growth to supply the bacterial cultures with the proper amount of carbonaceous material. To prevent contamination by the oat and red clover plants, the seeds were soaked three minutes in a 1-500 solution of mercuric chloride, washed in sterile distilled water three times and then planted in sterile agar plates. By this means the seeds were sprouted and these which were contaminated were discovered and rejected. The sprouted seeds were transferred from the plates to the flasks by means of the platinum needle. A block of the agar containing the sprouted seed was cut out and placed in the proper position on the medium in the flask. The flasks were then carefully observed for five days to insure the absence of contamination.

As all the flasks contained growing plants no attempt was made to exclude the light, but neither were they placed in the direct sunlight. They were kept on a table about eight feet from a large window facing the west. All the flasks were plugged with non-absorbent cotton and after inoculation a cap of parafined paper was placed over the mouth and held in place with a rubber band. While the plants did not develop rapidly the oats grew much faster than the clover for about three weeks, after which time both began to lose chlorophyl and by the end of the five weeks' experimental period, the majority of the plants had died. The oats and clover in the flasks inoculated with $\mathrm{A}$. chroococcum (IICM) and the clover in the flasks inoculated with B. radicicola showed a slight gain in growth and altho far from vigorous at the end of the experiment were still alive and growing slowly.

\section{ORGANISMS USEDD.}

The organisms used were A. chroococcum (HCM), A. vinelandii, A. beijerincliii and for the purpose of comparison, $B$. radicicola isolated from the nodules of sweet clover. The latter were isolated and purified especially for this series, and introduced to compare the effects of symbiotic and non-symbiotic organisms on the growth of the plant used. The results secured with it, however, were of no great significance. 
After the bacteria had remained undisturbed in the flasks for five weeks, transfers were made directly from the flasks into 50 ce. of the nitrogen-free dextrose solution, incubated for three weeks, and the nitrogen fixed determined in the usual manner. The total amount of nitrogen fixed by the bacteria themseives, as well as the amount fixed by the bacteria but due to the stimulative action of the plants on the bacterial activities, is shown in table VII. There was a stimulation of the nitrogen fixing power of the organisms due to the presence of a growing plant, especially noticeable in the case of $A$. vinelandii and $A$. chroococcum (HCM) and to some extent in the case of $A$. beijerinckii. A. vinelandii was stimulated thruout the entire series except when grown in sand in the presence of the algae. The oats and algae showed no TABLE VII-THE EFFECT OF! GROTING PIANTS ON THE NITROGEN FIXING POWER OF" PURE OULTURES.

\begin{tabular}{|c|c|c|c|c|c|c|c|c|c|}
\hline \multirow[b]{2}{*}{ Inoculum } & \multirow[b]{2}{*}{ Medium } & \multirow[b]{2}{*}{ Plant Used } & \multirow[b]{2}{*}{ (a) } & \multirow[b]{2}{*}{ (b) } & \multicolumn{5}{|c|}{ Nitrogen Fixed in Mgs. } \\
\hline & & & & & $(\mathrm{Av})$ & 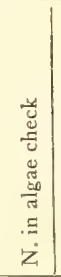 & 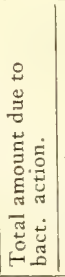 & 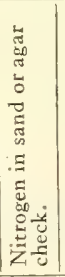 & 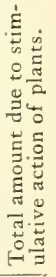 \\
\hline Algae -- & agar-.... & check _...... & 0.84 & $0.8 t$ & 0.84 & & & & \\
\hline Algae & $\operatorname{sand}$ & check ........ & 1.40 & 0.98 & 1.19 & & & & \\
\hline 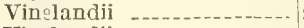 & agar...... & check ....... & 1.12 & 0.98 & 1.05 & & & & \\
\hline 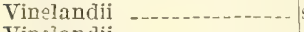 & $\operatorname{san} d_{-\ldots . . .}$ & check ......... & 1.40 & 1.40 & 1.40 & & & & \\
\hline Vinelandii _...... & agar__.... & oats $\ldots \ldots$ & 3.60 & 3.52 & 3.59 & & $3.5 t$ & 1.05 & 2.51 \\
\hline Vinelandii _.............. & agar $\ldots \ldots$ & red clover...- & 2.10 & $2.3 \mathrm{~S}$ & 2.24 & & 2.24 & 1.05 & 1.19 \\
\hline Vinelandii & g gar_-...- & algas ...... & 4.20 & lost & 4.20 & 0.84 & 3.36 & 1.05 & 2.31 \\
\hline 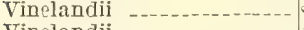 & $\sin 1 . \ldots+-$ & oats _...... & 4.20 & 4.06 & 4.13 & & 4.13 & 1.40 & 2.73 \\
\hline Vinelandii & fand...... & red clover...- & 4.48 & 4.06 & 4.27 & & 4.27 & 1.40 & 2.87 \\
\hline Vinelandii _... & Fand & a]gae $\ldots . .$. & 2.52 & 2.80 & 2.66 & 1.19 & 1.47 & 1.40 & 0.07 \\
\hline Chroococcum (HCM) -.-- & agar........ & check ......- & 0.00 & 0.00 & 0.00 & & & & \\
\hline Chroococeum (HOM) -..- & $\operatorname{sand}$ & eheck _....... & $0.2 \mathrm{~s}$ & 0.14 & 0.21 & & & & \\
\hline Chroococcum ( $\mathrm{H}$ CM) & agar__. & oats $\ldots \ldots$ & 0.28 & 0.44 & 0.36 & & 0.36 & 0.00 & 0.35 \\
\hline Chroococeum ( $\mathrm{HCM}$ ) .... & agar...... & red elover-_.- & $1.8^{\prime}$ & 3.22 & 2.52 & . & 2.52 & 0.00 & 2.52 \\
\hline Chroococeum (HCM) ... & $7 \mathrm{gar}-$ & algas _....... & 3.92 & 3.50 & 3.71 & 0.84 & 2.87 & 0.00 & 2.87 \\
\hline Chroococcum (HCMI) -... & $\operatorname{sand}$ & oats _....... & 0.28 & 0.56 & 0.42 & & 0.42 & 0.21 & 0.21 \\
\hline Chroococeum (HCM) .... & $\operatorname{sand}$ & red elover.... & 0.28 & Iost & 0.28 & & 0.28 & 0.21 & 0.07 \\
\hline Chroococeum (HOMI) & $\operatorname{sand}$ & algae ........ & 3.22 & 5.18 & 4.20 & 1.19 & 3.01 & 0.21 & 2.80 \\
\hline Beijerinekii _............... & agar & chock ...... & 0.00 & 0.00 & 0.00 & & & & \\
\hline 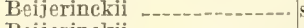 & $\operatorname{san} d_{-\ldots} \ldots$ & check _....... & 0.28 & 0.42 & 0.35 & & & & \\
\hline 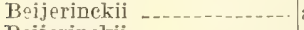 & agar.....- & oats & 0.14 & 0.00 & 0.07 & & 0.07 & 0.00 & 0.07 \\
\hline Beijerinckii _................ & agar.......... & red clover.... & 1.40 & 1.40 & 1.40 & & 1.40 & 0.00 & $1.40^{\mathrm{P}}$ \\
\hline 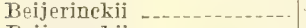 & gar....... & algae .....- & 0.00 & 0.00 & 0.00 & 0.84 & ---- & $---n$ & ---- \\
\hline Boijennckii _.... & $\operatorname{sand} \lambda_{-----}$ & oats & 1.39 & 1.39 & 1.39 & & 1.39 & 0.35 & 1.01 \\
\hline 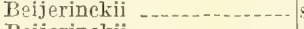 & $\sin 1 \ldots \ldots$ & red clover..-- & 1.39 & 1.39 & 1.39 & & 1.39 & 0.35 & 1.04 \\
\hline Beijerinckii -..-........ & sand & algae ....... & 1.39 & 1.40 & 1.40 & 1.19 & 0.21 & 0.35 & $-\cdots$ \\
\hline B. rad., S. clo. _..... & 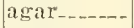 & oats ........ & 0.14 & 0.14 & .014 & & 0.14 & & \\
\hline B. rad., S. clo. ...... & agar...... & red clover...- & 0.14 & 0.74 & .014 & & 0.14 & & \\
\hline B. rad., S. clo. _...... & ๆgar_..... & algae $\ldots . . . .$. & 0.56 & 0.56 & 0.56 & 0.84 & $-\infty--$ & & \\
\hline B. rad., S. clo. & sand & oats & 0.42 & 0.00 & 0.21 & & 0.21 & & \\
\hline B. rad., S. clo. ......... & sand_..... & red clover.... & 0.14 & 0.00 & 0.07 & & 0.07 & & \\
\hline B. rad., S. clo. ....... & Sand & algae _....... & 0.42 & 0.56 & 0.49 & 1.19 & $-\cdots$ & & \\
\hline
\end{tabular}


difference when grown on the agar and in the sand medium the greatest stimulation was produced by the red clover. The activities of $A$. chroococcum were stimulated to the greatest extent by the presence of algae in both sand and agar, the oats gave a poor stimulation in both eases, and red clover gave good results in the agar but not in the sand.

The nitrogen fixing power of $A$. beijerinckii was retarded by the presence of algae, but was stimulated by red clover in both the agar and sand. The oats stimulated this organism only when grown on the agar. The nitrogen fixing power of $B$. radicicota was so low thruout the experiment that the results are not considered.

\section{CONCLUSIONS FROM LABORATORY STUDIES,}

1. Transfers made on a nitrogen free dextrose agar more often than once each week were detrimental to the nitrogen fixing power of azotobacter and other large celled nitrogen fixing organisms of the same type.

2. Transfers made once each week into a pure sand medium containing some carbonaceous material were beneficial to the nitrogen fixing power of the azotobacter in general, but the effect on $A$. beijerinckii was detrimental.

3. 'The nitrogen fixing power of $A$. vinelandii was stimulated to a marked extent when grown in large flasks for five weeks in the presence of red clover and oats on both agar and sand. It was stimulated by the presence of algae when grown on agar but not when grown on sand.

The nitrogen fixing power of $A$. chroococcum was stimulated markedly when grown on agar for five weeks in the presence of growing oats and red clover, but to a less extent when grown with the same plants in sand. The greatest stimulation for this organism was produced by growing it in the presence of algae in either sand or agar for the same period of time.

5. The nitrogen fixing power of A. beijerinctii was stimulated by the presence of red clover when grown on either sand or agar, and by oats when grown in sand. Algae in either agar or sand appeared to have a depressing effect on the nitrogen fixing power of this organism.

\section{GREENHOUSE STUDIES.}

At the conclusion of the first experiment the eight organisms used in the laboratory series 1,2 and 3 were also inoculated into soils in pots in the greenhouse. Ground oats straw or ground clover hay was added to these soils and the nitrogen fixing effieiency of the organisms both in fallow soils and in the presence of growing oats plants determined. Three experiments were carried out in this test, as soon as the soil in which one crop had been 
grown was sampled, it was immediately reseeded and another crop grown. Strict account was kept of the amount of nitrogen added in the seed and in the organic matter. The dry weight of the crop and the N. content as well as the nitrogen content of the soil was determined at the end of each experiment.

The soil used thruout the experiment was of the type classified by the United States Bureau of Soils as Miami silt loam, and according to tests in the laboratory did not contain azotobacter or any similar organisms. A large amount of this soil was thoroly air dried, sieved and mixed. Ten pounds were placed in each of eighty glazed pots, seventy-two of which were given the following treatment: Half, or thirty-six pots received an application of 22.68 grams ground oats straw, and the other half received an equivalent amount of ground red clover hay. This application (22.68 grams) was equivalent to a five-ton application of this material per acre. The ground material was thoroly incorporated in the soil, which was packed firmly in the pots. The pots used were slazed on the inside and made tight so there was no loss by reaching, neither was there any drainage provided.

\section{METHODS OF INOCULATION.}

The inoculum used was the dextrose solution described above. $1500 \mathrm{e} \mathrm{e} \mathrm{were} \mathrm{placed} \mathrm{in} \mathrm{each} \mathrm{of} \mathrm{six} 2 \mathrm{~L}$. flasks, inoculated with the organism desired and incubated for seven days. Microscopic examinations were made at the end of the incubation period to insure vigorous growth and the purity of the culture. 150 ec of the solution was used as the inoculum for each pot. This was poured over the surface of the dry soil and washed into it by the addition of sufficient water to bring the moisture content up to the optimum, in this ease $25 \%$. The pots were then weighed, covered with a cloth, and allowed to remain undisturbed for three days, in order to permit the moisture to become thoroly distributed thruout the soil. The pots were then arranged in the following manner and seeded to oats.

Thirty grains of Early Champion oats were planted in each pot at each seeding. They were planted at five points. One in the center of the pot and the other four were arranged between the center and the edge at equal distances apart. Six seeds were planted at each place and when the plants appeared they were thinned out and but one plant left in each place. The discarded plants were allowed to remain and decay on the soil in the pot from which they were drawn.

The length of the growing period was determined by the appearance of the seed-bearing spike. This period varied slightly in each of the series, the first closed in sixty-three days, the second in sixty-nine days, and the third in seventy days after planting. 
PLAN OF EXPERIMENT

\begin{tabular}{|c|c|c|c|c|}
\hline Pot. No. & & \multicolumn{2}{|c|}{ Treatment } & Inoculation \\
\hline & & & & \\
\hline $1-3=-$ & Fallow --.-- & Uats straw - & $--\infty$ & A. chroococeum (HCLI) \\
\hline $2-4+\ldots$ & Cropped_..- & Oats straw - & - - - - n- - - - & A. chroococcum (HCM) \\
\hline $5-7-\cdots$ & Fallow _-_- & Clover hay - & --nn-n- & A. chroococeum (HCM) \\
\hline $6-8 \ldots$ & Cropped & Clover hay . & 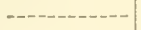 & A. ehroococeum (HCM) \\
\hline $9-11$ & Fallow _-.-- & Oats straw - & $-\ldots-n+-n-\infty$ & A. ehroococeum \\
\hline $10-12$ & Cropped & Oats straw & -- & A. ehroococcum \\
\hline $13-15 \ldots$ & Fallow -...- & Clover hay - & -n-non & A. chrooeoceum \\
\hline $14-16 \ldots$ & Cropped & Clover hay - & 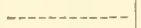 & A. chroococeum \\
\hline $17-19 \ldots$ & Fallow $\ldots$ & Oats straw & -...- & A. beijerinckii \\
\hline $18-20$ & Cropped_... & Oats straw - & - - - n- & A. beijerinckii \\
\hline $21-23$ & Eallow _-_-- & Clover hay. & -n-non & A. beijerinckii \\
\hline $22-24 \ldots \ldots-$ & Cropped_._- & Clover hay. & n-n-n-n- & A. beijerinckii \\
\hline $25-27$ & Fallow $\ldots \ldots$ & Oats straw. & n-n- & A. vinelandii \\
\hline $26-28 \ldots \ldots \ldots$ & Oropped & Oats straw. & $n-n-m-n-m$ & A. vinelandii \\
\hline $29-31 \ldots \ldots$ & Fallow _...- & Clover hay. & $-\infty-\infty-\cdots-\cdots$ & A. vinelandii \\
\hline $30-32-$ & Cropped & Olover hay & $-\ldots-\cdots$ & A. vinelandii \\
\hline $33-315 \ldots$ & Fallow _..... & Oats straw. & $\ldots-\cdots$ & $261 \mathrm{D}$ \\
\hline $31-36 \ldots \ldots$ & Cropped & Oats straw & $-n-m-\infty n-\infty$ & 26) D. \\
\hline $37-39$ & Fallow _...- & Clover hay & $-\ldots-n-n-\infty$ & $26 \quad \mathrm{D}$ \\
\hline $38-40 \ldots \ldots$ & Oropped & Clover hay . & 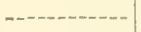 & $26 \mathrm{D}$ \\
\hline $41-43 \ldots$ & Fallow -..-- & Oats straw. & man- & $27 \quad \mathrm{D}$ \\
\hline $42-44 \ldots \ldots$ & Cropped & Oats straw & $\ldots-n+\cdots$ & $27 \mathrm{D}$ \\
\hline $45-47 \ldots \ldots$ & Fallow _... & Clover hay & 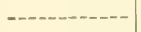 & $27 \mathrm{D}$ \\
\hline $46-48 \ldots \ldots$ & Cropped & Clover hay & n-n-n-n- & $27 \mathrm{D}$ \\
\hline $49-51 \ldots$ & Fallow _.... & Oats straw. & $--\cdots+-m-n-\infty$ & $22 \mathrm{D}$ \\
\hline $50-52 \ldots \ldots$ & Cropped & Oats straw & $-\ldots-n-\cdots---$ & $22 \mathrm{D}$ \\
\hline $53-55$ & Fallow _- & Clover hay & & $22 \mathrm{D}$ \\
\hline $54-56$ & Cropped & Clover hay. & $\ldots$ & $22 \mathrm{D}$ \\
\hline $57-59 \ldots$ & Fallow & Oats straw. & $-\cdots$ & $4 \mathrm{D}$ \\
\hline $58-60_{\ldots} \ldots$ & Cropped & Oats straw & $n---n-\infty-\infty$ & $4 \mathrm{D}$ \\
\hline $61-63 \ldots \ldots$ & Fallow -..-- & Clover hay & $-\ldots-\ldots-\cdots$ & $4 \mathrm{D}$ \\
\hline $63-6 t \ldots$ & Cropped & Clover hay. & -------- & 4 D. \\
\hline $65-67 \ldots$ & Fallow _-_ & Oats straw & - & Mixed culture \\
\hline $66-68 \ldots \ldots$ & Cropped & Outs 'straw & - & Mixed culture \\
\hline $69-71 \ldots$ & Fallow _...- & Clover hay & 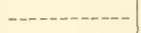 & Mixed culture \\
\hline $70-72 \ldots$ & Cropped._- & Clover hay & $\ldots-n-\cdots$ & Mixed culture \\
\hline $73-74 \ldots$ & Fallow _._- & Oats straw & 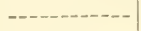 & Check \\
\hline $75-76 \ldots$ & Oropped & Oats straw. & -non- & Check \\
\hline $77-78 \ldots$ & Fallow $\ldots \ldots$ & Clover hay & n-n-n-n & Check \\
\hline $79-80 \ldots \ldots$ & Cropped_... & Clover hay. & - n- $-\cdots-\cdots$ & Check \\
\hline
\end{tabular}

The pots were watered with tap water about every other day and were weighed weekly. The loss in weight was replaced with water in order to keep the moisture content at the optimum. The growth of the plants was carefully noted and recorded by means of photographs at different periods. The harvested plants were dried, weighed, and the total nitrogen content determined by the Kjeldahl method.

At the close of each series of experiments the soils were removed from the pots, placed on a sterile oil cloth, thoroly mixed, sampled and returned to the original pot. The sample taken at this time approximated 500 grams dry weight. The pots were seeded again as soon as possible and the experiment continued. During the short period between sampling and reseeding the moisture content was kept at the optimum. 
The preliminary analyses, showing the nitrogen content of the original air dried soil, and of the same soil mixed with the ground oats or clover are as follows:

\footnotetext{
22.68 grs. ground oats straw contained.... $0.1416 \mathrm{grs}$. N. av. 6 dets. 22.68 grs. clover hay contained...............4153 grs. N. av. 6 dets. $10 \mathrm{lbs}$. original soil contained................... $3494 \mathrm{grs} . \mathrm{N}$. av. 6 dets. 10 lbs. original soil + oats straw contained. .2.4910 grs. N. av. 6 dets. 10 lbs. original soil + clover hay contained. .2.7647 grs. N. av. 6 dets.
}

\section{ACTION OF DENITRIFYING BACTERIA.}

Some of the plants were very much stunted in their growth and an experiment was conducted to determine whether this was due to action by the denitrifying organisms. Samples weighing about six or eight grams were drawn from near the center of each pot by means of a sterile corkborer and placed immediately in sterile tubes. Sterile water was added and a soil suspension made from which inoculations were made into Giltay's denitrifying solution. The solution was incubated three weeks and the amount of nitrate nitrogen as well as the total nitrogen determined, the first by the aluminum reduction method of Potter and Snyder, and the second by the official method. The aluminum reduction was carried out by aeration, thus leaving the original solution available for analysis for total nitrogen. The results given in table VIII show that the denitrifying organisms were not the limiting factor in the growth of plants. Only the five soils in pots Nos. 29, 45, 62, 64 and 66 show any great loss in nitrogen and some of the pots show an actual gain in total nitrogen content. This gain is particularly noticeable in the soils inoculated with A. beijerinckii, No. 26 and in the check pots.

TABLE VIII-THE ACTIVITIES OF THE DENITRIFYING BACTERIA IN THE SOILS THREE WEEKS AFTER THE START OF THE EXPERIMENT

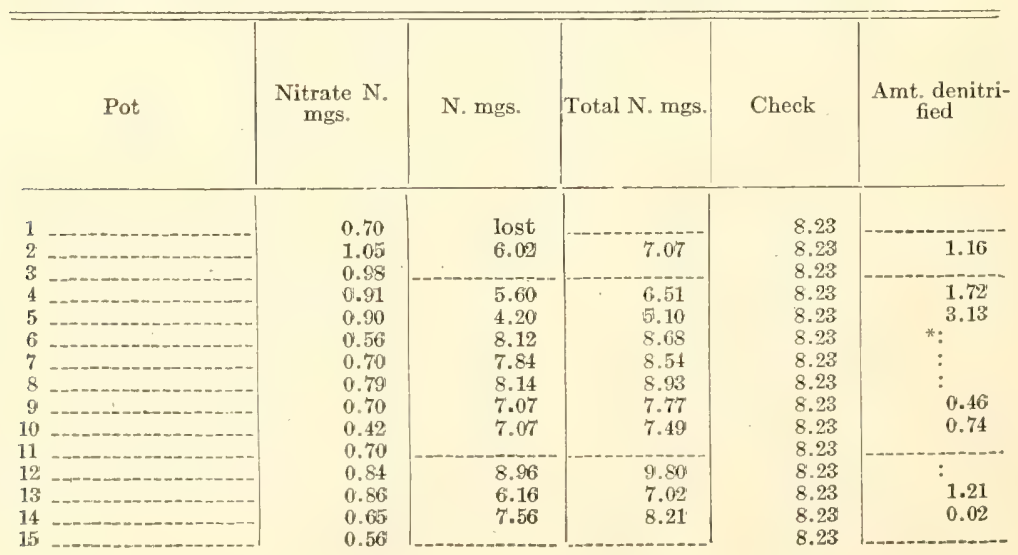


TABLE VIII-ConTINUED.

\begin{tabular}{|c|c|c|c|c|c|c|}
\hline & Pot & $\begin{array}{c}\text { Vitrate } \\
\text { mgs. }\end{array}$ & N. mgs. & Total N. mgs. & Check & $\begin{array}{l}\text { Amt denitri- } \\
\text { fied }\end{array}$ \\
\hline 16 & $-1-10-1$ & 1.71 & 6.16 & 7.87 & 8.23 & 0.36 \\
\hline 17 & - - & 0.56 & 7.56 & 8.12 & 8.23 & 0.11 \\
\hline 15 & - & 0.96 & 7.70 & 8.66 & 8.23 & : \\
\hline 19 & 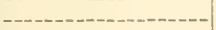 & $0 .+2$ & 8.61 & 9.03 & 8.23 & : \\
\hline 20 & 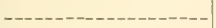 & 0.84 & 8.40 & 9.24 & 8.23 & : \\
\hline 21 & 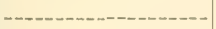 & 0.84 & 7.91 & 8.75 & 8.23 & : \\
\hline 22 & 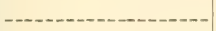 & 0.56 & 9.38 & 9.94 & 8.23 & : \\
\hline 23 & - & 0.70 & 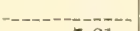 & 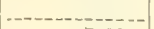 & 8.23 & \\
\hline 24 & 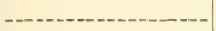 & 0.78 & 7.21 & 7.98 & 8.23 & 0.25 \\
\hline 25 & 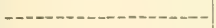 & 0.86 & 6.44 & 7.30 & 8.23 & 0.93 \\
\hline 26 & 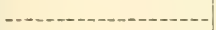 & 0.06 & 7.42 & 7.48 & 8.23 & 0.75 \\
\hline 27 & n-n-n & 0.58 & 8.04 & 8.62 & 8.23 & : \\
\hline 28 & 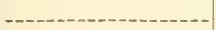 & 0.87 & 7.28 & 8.15 & 8.23 & 0.08 \\
\hline 29 & nomenten & 0.56 & 5.04 & 5.60 & 8.23 & 2.63 \\
\hline 30 & non & 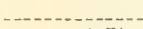 & 6.30 & & 8.23 & $\rightarrow$ \\
\hline 31 & 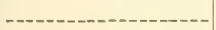 & 1.54 & 5.32 & 6.86 & 8.23 & 1.37 \\
\hline 32 & 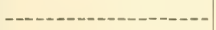 & 0.43 & 9.10 & 9.53 & 8.23 & : \\
\hline 33 & - & 0.70 & $-1-2$ & - n. - n- & 8.23 & 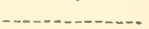 \\
\hline 34 & non & 0.56 & 8.54 & 3.10 & 8.23 & : \\
\hline 3.5 & non & 0.98 & 7.56 & 8.54 & 8.23 & : \\
\hline 36 & 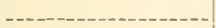 & 0.79 & 8.68 & 9.47 & 8.23 & : \\
\hline 37 & 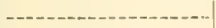 & $0.86 i$ & 7.00 & 7.86 & 8.23 & 0.37 \\
\hline 38 & - - - - - - - - - - & 0.90 & 6.44 & $7.3 \pm$ & 8.23 & 0.89 \\
\hline 39 & 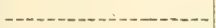 & 1.51 & 6.58 & 8.12 & 8.23 & 0.11 \\
\hline 40 & 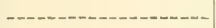 & 0.63 & 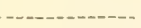 & 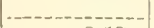 & 8.23 & 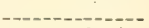 \\
\hline 41 & 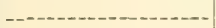 & 0.63 & 1.00 & 8.19 & 8.23 & 0.04 \\
\hline $4 \pi$ & n-2-1 & 0.56 & 4.90 & 5.46 & 8.23 & 2.77 \\
\hline 43 & 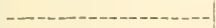 & 0.70 & 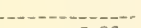 & $=-\infty$ & 8.23 & 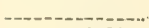 \\
\hline 41 & 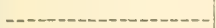 & 0.98 & 6.86 & 7.81 & 8.23 & 0.39 \\
\hline 45 & 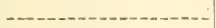 & 0.77 & 2.80 & 3.57 & 9.23 & 4.66 \\
\hline 46 & hon & 1.05 & 6.30 & 7.35 & 8.23 & 0.88 \\
\hline 47 & 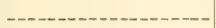 & 0.77 & 6.16 & 7.35 & 8.23 & 0.85 \\
\hline 48 & 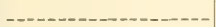 & 0.56 & 6.02 & 6.58 & 8.23 & 1.65 \\
\hline 49. & - & 0.91 & 7.28 & 8.32 & 8.23 & $:$ \\
\hline 50 & 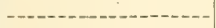 & 0.91 & 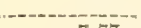 & 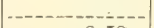 & 8.23 & \\
\hline 51 & 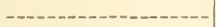 & 0.81 & 7.77 & 8.58 & 8.23 & : \\
\hline 52 & - & 0.50 & 7.70 & 8.20 & 8.23 & 0.03 \\
\hline 53 & 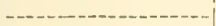 & 0.77 & 8.12 & 8.89 & 8.23 & : \\
\hline 51 & 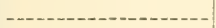 & 0.49 & 7.56 & 8.05 & 8.23 & 0.18 \\
\hline 55 & 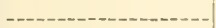 & 0.86 & 6.44 & 7.30 & 8.23 & 0.83 \\
\hline 56 & 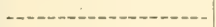 & 1.00 & 6.09 & 7.09 & 8.23 & 1.14 \\
\hline 57 & 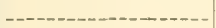 & 0.86 & 5.46 & 6.32 & 8.23 & 1.81 \\
\hline $5 S$ & 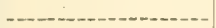 & 0.86 & 7.70 & 8.56 & 8.23 & : \\
\hline 59 & n-m-n & 0.86 & 5.60 & 6.46 & 8.23 & 1.77 \\
\hline 60 & 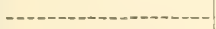 & 1.33 & 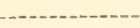 & 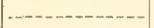 & 8.23 & $\ldots$ \\
\hline 61 & 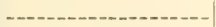 & 0.91 & 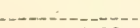 & $-\ldots-$ & $8.2: 3$ & $\ldots$ \\
\hline 62 & 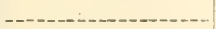 & 0.78 & 1.96 & 2.71 & 8.23 & 5.49 \\
\hline 63 & 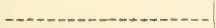 & 1.26 & 5.60 & 6.86 & 8.23 & 1.37 \\
\hline 64 & - & 1.31 & 4.76 & 6.07 & 8.23 & $2.16^{\circ}$ \\
\hline 65 & - - - - - & $1 . ? 6$ & 7.28 & 8.54 & 8.23 & : \\
\hline 66 & 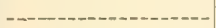 & 0.93 & 1.54 & 2.52 & 8.23 & 5.71 \\
\hline 67 & - & ใ. 14 & 7.28 & 7.42 & 8.23 & 0.81 \\
\hline 68 & - & 0.70 & 6.16 & 6.86 & 8.23 & 1.37 \\
\hline 69 & 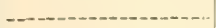 & 0.56 & 6.72 & 7.28 & 8.23 & 0.95 \\
\hline 70 & - & 0.81 & 4.62 & 5.46 & 8.23 & 2.77 \\
\hline 71 & - & 0.49 & 8.40 & 8.89 & 8.23 & : \\
\hline 72 & h-nond & 0.67 & 7.98 & 8.65 & 8.23 & : \\
\hline 73 & 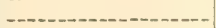 & 0.87 . & 6.02 & 6.89 & 8.23 & 1.34 \\
\hline 74 & - & 1.05 & 7.70 & 8.75 & 8.23 & : \\
\hline 75 & - n-m & $0.65 i$ & 9.80 & 10.43 & 8.23 & : \\
\hline 76 & $\ldots \ldots-1-1-\cdots$ & 0.51 & 8.12 & 8.63 & 8.23 & : \\
\hline
\end{tabular}

*No denitrifieation is shown by : 


\section{PRELIMINARY TESTS FOR NITROGEN FIXATION.}

To discover the action of the bacteria in the inoculated soils samples were taken from the fallow pots four weeks after t e start of the experiment and their total nitrogen content determined. Table IX shows a gain in the nitrogen content over the original soil and the check soils but the actual gain due to the action of the bacteria introduced was very slight. Organisms 22, 4 and the mixed cultures showed no gain whatever, and the others showed only a slight gain in those soils to which clover had been

TABLE IX-THE ACTIVITY OF THE BACTERIA IN THE INOCULATED FALLOW SOILS AFTER FOUR WEEKS.

Grams of Nitrogen Per 10 Pounds of Soil

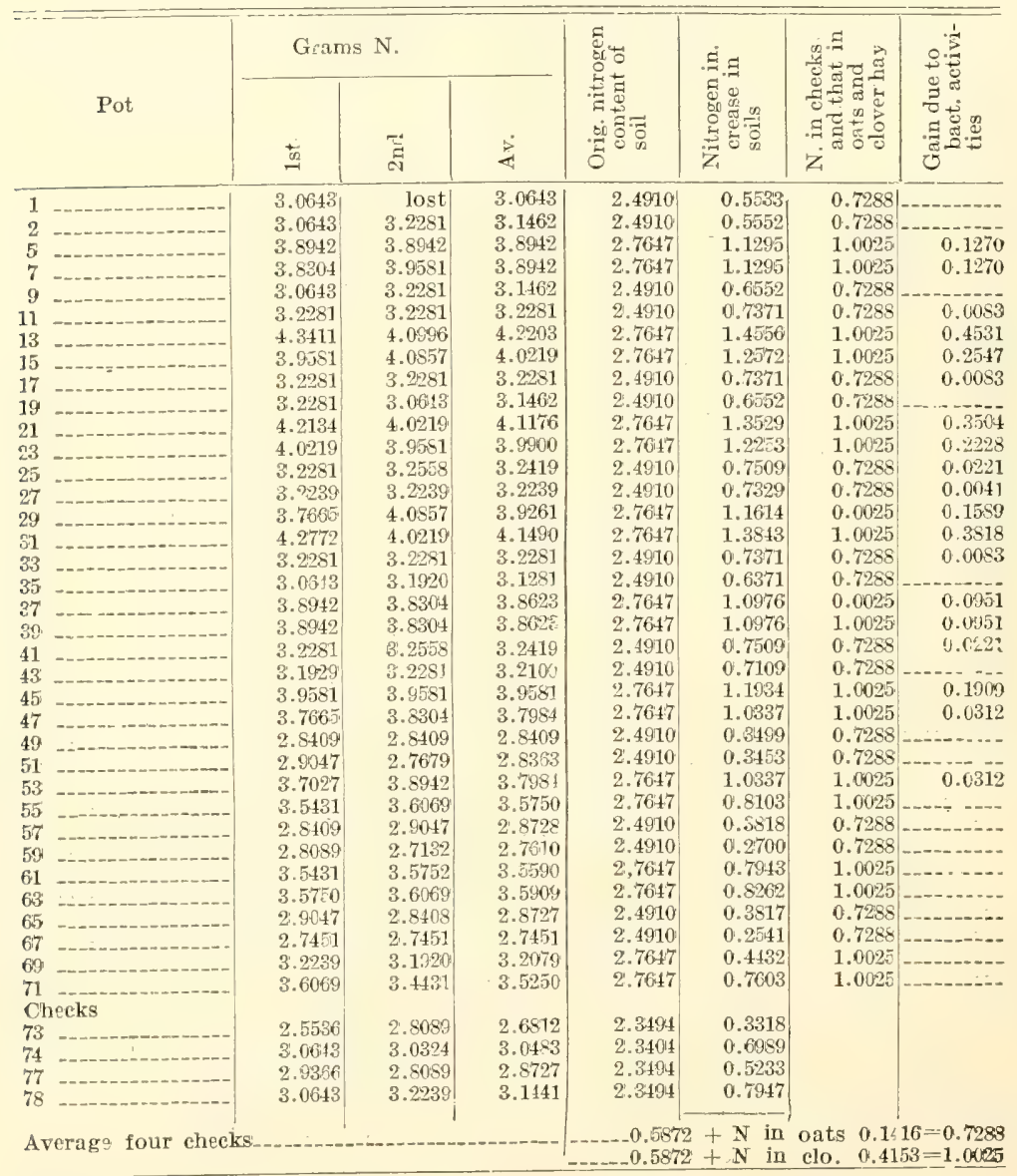


added. This difference may have been due to variation in the rate of decomposition between the elover and the straw.

At the end of the three growing periods the soil in each pot was sampled and the total nitrogen content of both the soil and the entire crop determined. The amount of nitrogen found in the determinations and its relation to the total amount due to the bacterial activities is given in three separate tables, one for each growing pericd. From these complete tables three condensed tables have been made as follows: For the first growing period, table $\mathrm{X}$, for the second growing period, table XI, for the third growing period, table XII, and a recapitulation table XIII.

TABLE X-THE NITROGEN FIXED BY BACTERIA-FIRST PERIOD

(Condensed from Appendix Table I.)

\begin{tabular}{|c|c|c|c|c|c|c|c|}
\hline \multirow[b]{2}{*}{ 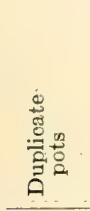 } & \multirow{2}{*}{\multicolumn{2}{|c|}{ Treatment }} & \multirow[b]{2}{*}{$\begin{array}{l}\text { Bact. Inoculum } \\
\text { Used }\end{array}$} & \multicolumn{4}{|c|}{ Grams N. per 10 Pounds Soil } \\
\hline & & & & 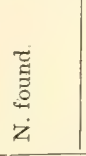 & 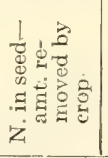 & 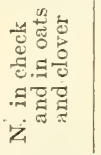 & 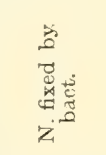 \\
\hline $1 \div 3-$ & F & oats .... & A. chrooc. (HCM) & 3.3499 & 3.3833 & 3.6232 & \\
\hline $2-4-$ & C & oats & A. chrooc. (HCM) & 2.9 & 2.9870 & 3.7309 & \\
\hline $5-7-$ & & lover -. & A, chrooc. (HC & 4.3058 & 4.3488 & $3.596 \hat{3}$ & 0.45 \\
\hline $6-S_{--}$ & & elover -. & A. chrooe. (HCM) & $4: 1808$ & 4.2684 & $4.00-16$ & 0.2638 \\
\hline $9-11--$ & F & oats _.... & A. chrooe. & 3.2210 & 3.2532 & 3.6232 & \\
\hline $10=12$ & $\mathrm{C}$ & oats .... & A. chrooe. - & 3.5380 & 3.5508 & 3.7309 & \\
\hline$-15 \ldots$ & & clover - & A. chrooc. & 26 & 4.6183 & 3.8963 & 0.72 \\
\hline $1 \pm-16 \ldots$ & & ciover -. & A. chrooc. & 4.4928 & 4.5787 & 4.0046 & $0 . \overline{3} 741$ \\
\hline $17-19$ & & oats $\ldots$ & A. beyer. - & 5.1701 & 5.2218 & 3.6 & 1.59 \\
\hline $18-20-=$ & & oats ......... & A. beyer. - & & 5.2824 & 3.7 & 1.5515 \\
\hline $21-23 \ldots$ & & elover ........ & A. keyer. - & 4.4594 & 4.4827 & 3.8963 & 0.5864 \\
\hline $2-24=-$ & & clover ... & A. beyer. & 1 & 4.6613 & 4.0 & 0.65 \\
\hline $25-27 \ldots$ & & oats $\ldots \ldots$ & A. vine. - & 3. & 3.9659 & 3.6232 & 0.3427 \\
\hline $36-28=$ & & oats ........... & A. vine: - & 5.1120 & 5.1794 & 3.7309 & 1.4185 \\
\hline $22-31 \ldots$ & & clover = & A. vine. - & 2.4572 & 2.4817 & 3.8963 & 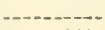 \\
\hline $30-32$ & & clover & A. vine. -- & 4.2388 & 4.3457 & 4.0046 & 0.3411 \\
\hline $33-35_{--}$ & $\mathrm{F}^{\mathrm{v}}$ & oats _.......... & No. 26 _..... & 3. & 3.5235 & 3.6232 & \\
\hline $34-36 \ldots$ & & oats .......... & No, $26 \ldots$ & 3.5170 & 5.5133 & 3.7309 & \\
\hline $37-38--$ & & clover ... & No. $26 \ldots$ & 23 & 4.5271 & 3.8963 & 0.6308 \\
\hline $38-40 \ldots$ & & clover _....... & No. $26 \ldots$ & 22 & 4.68 & 4.0046 & 0.6787 \\
\hline $41-43 \ldots$ & & oats _........ & No $27 \ldots$ & $3,6 \pm 58$ & 3.6822 & 3.6232 & 0.0590 \\
\hline $42-44 \ldots$ & & oats & No. $27 \ldots$ & 20 & 3.6217 & 3.7309 & $\therefore-\ldots=-$ \\
\hline $45-47=$ & & clover & No. $27=\ldots$ & 23 & 4.5473 & 3.8963 & 0.6510 \\
\hline $46-48$ & & clover -...-. & In. $27 \ldots$ & 4.3114 & t. 4195 & 4.0046 & 0.4149 \\
\hline $49-51$ & & oats _.......... & No. $22 \ldots$ & 3.4101 & 3.4442 & 3.6232 & 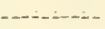 \\
\hline $50-52$ & & oats $\ldots$ & No. $22 \ldots$ & 3.5323 & 3.5519 & 3.7 & \\
\hline $53-5 \overline{1}$ & & clover --- & No. 22 _...... & 4.4001 & 4.4441 & 3.8963 & 0.5478 \\
\hline $54-56 \ldots$ & & elover ... & |โ.0. $22 \ldots$ & 4.3114 & 4.3866 & 4.0046 & 0.3320 \\
\hline $57-50$ & & oats - & No. 1 .... & 3.6065 & 3.6425 & 3.6232 & 0.0193 \\
\hline $58-60$ & O & oats & No. $4 \ldots$ & 3.5006 & 3.5323 & 3.7309 & \\
\hline $61-63 \ldots$ & $F$ & clover - & No. 4 & 4.4630 & 4.5076 & 3.8963 & 0.6113 \\
\hline $63-64-$ & & clover _-_.... & No. 4 , & 4.3023 & 4.3965 & 4.0946 & 0.3919 \\
\hline $65-67-$ & & oats & Mixed culture -.. & 3.3865 & 3.4203 & 3.6232 & \\
\hline $66-68=$ & & cats ___- & Mixed eulture -.. & 3.6038 & 3.6021 & 3.7309 & \\
\hline $69-71--$ & & clover -...-- & Mixed culture ... & 4.3787 & 4.4123 & 3.8963 & 0.6 \\
\hline $70-72$ & & clover _. & Mixed culture .... & 4.4720 & 4.5794 & 4.0046 & 0.5748 \\
\hline $73-74$ & & . notbing ..... & Check _.............. & 3.5949 & 3.6301 . & & \\
\hline $75-76$ & & - nothing ----- & $\begin{array}{l}\text { Cheek ------- } \\
\text { Cheek -- }\end{array}$ & 3.5085 & $\begin{array}{l}3.5689 \\
3.3329\end{array}$ & & \\
\hline $79-80=$ & & $\begin{aligned} \text { nothing } & =-.- \\
\text { nothing } & =-\ldots-\end{aligned}$ & $\begin{array}{l}\text { Oneek } \\
\text { Check }\end{array}$ & $\begin{array}{l}3.3002 \\
3.5403\end{array}$ & $\begin{array}{l}3.3332 \\
3.6097\end{array}$ & & \\
\hline
\end{tabular}




\section{FIRST GROWING PERIOD.}

The determinations for this period are shown in appendix table I and in condensed table $\mathrm{X}$. As indicated by table IX, there was a steady increase in the total amount of nitrogen fixed in all the soils. This increase is still more marked if the last columns of tables IX and $\mathrm{X}$ are compared. The bacteria were increasingly active in fixing the free atmospheric nitrogen and in practically every case the total amount fixed due to the bacterial solution was more than doubled during the latter five weeks of this series.

These activities may be divided into two elasses, as the bacteria were more markedly affected by the presence of elover hay or of oats straw. In the first class A. chroococcum, A. chroococcum $(H C M I)$, No. 26, No. 22 and the Mixed Culture stood out prominently. None of these four organisms showed any fixation due to the presence of the decaying oats straw, but they did show appreciable gains due to the presence of the clover hay. The presence of the oats straw had apparently either inhibited the activities of the organisms or increased the activities of the other forms that are incapable of fixing nitrogen for their own use and have utilized that fixed by the inoculating organisms. Organisms 4 and 27 showed a decided stimulation due to the elover hay and were able to utilize the oats straw as a source of energy.

$A$ beijerincki and $A$. vinelandii were more markedly affected by the presence of oats straw. The stimulation of the activities of the former due to the presence of the decaying elover was parallel to that of the other organisms, and in addition the presence of the decaying oats straw stimulated its nitrogen fixing powers to over $250 \%$ of that of any other organism in the series with the single exception of $A$. vinelandii. On the other hand, $A$. vinelandi, while showing a marked stimulation due to the presence of the oats, also showed that the clover hay affected its activities much the same as the oats straw affected the other organisms, that is, the presence of the decaying clover hay in the cropped soils, decreased its nitrogen-fixing power, and in the fallow soils, completely inhibited it.

\section{SECOND GROWING PERIOD.}

The results for this period are shown in appendix table II, the more important parts of which are repeated in condensed table XI. In comparison with the first growing period the results for the second period are decidedly lower thruout the second series. Not only are the total amounts of nitrogen found lower, but also the total amount of dry matter produced in the crop, indicating a possible direct relation between bacterial action and crop yields. These low results are explained by the fact that this series as 
grown during the hottest part of the summer, the pots being planted in the latter part of June and harvested during the earlier part of August. The results confirm those given in Table X except that in this series the only organism stimulated by the presence of the decaying oats straw was organism 27 in the cropped pots. Each of the inoculated organisms showed a direct stimulation due to the presence of the clover hay.

The organisms may be divided into two classes according as their activities are stimulated or retarded by the presence of

TIABLE XI-THE NITROGEN FIXED BY BACTERTA-SECOND PERIOD. (Condensed from appendix Table 2.)

\begin{tabular}{|c|c|c|c|c|c|c|}
\hline \multirow[b]{2}{*}{$\begin{array}{c}\text { Dupli- } \\
\text { cate } \\
\text { Pots }\end{array}$} & \multirow[b]{2}{*}{ Treatment } & \multirow[b]{2}{*}{$\begin{array}{c}\text { Bacterial inoculum } \\
\text { used. }\end{array}$} & \multicolumn{4}{|c|}{ Grams Nitrogen per 10 lbs. soil. } \\
\hline & & & 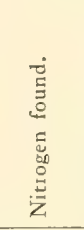 & 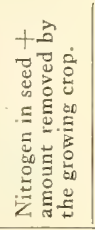 & 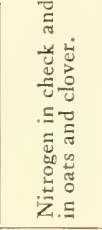 & 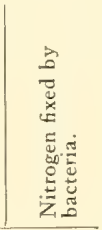 \\
\hline $1-3 \ldots$ & F. oats --- & A. chroococeum (HCMI)-- & 2.7310 & 3.0128 & 3.3370 & \\
\hline $2-4-\cdots$ & O. oats $\ldots$ & A. chroococcum (HCM) -- & 2.8218 & 3.0916 & 3.1866 & \\
\hline $5-7 \ldots$ & F. clover -. & A. chroococcum (HIOM)-- & 3.3205 & 3.6592 & 3.6107 & 485 \\
\hline $6-8$ & C. clover _... & A. chroococeum ( $\mathrm{HCM})_{--}$ & 3.3123 & 3.6402 & 3.4603 & 0.1799 \\
\hline $9-11$ & F. oats - - & A. chroococeum _-...... & 2.6867 & 2.9607 & 3.3370 & \\
\hline $10-12$ & C. oats $\ldots$ & A. chroococeum -.. & 2.5479 & 2.7947 & 3.1866 & \\
\hline $13-15 \ldots$ & F. clover _- -- & A. chroococcum & 3.5242 & 3.8836 & 3.6107 & 0.2729 \\
\hline $14-16 \ldots$ & C. clover - & A. chroococeum & 3.1813 & 3.4901 & 3.4603 & 0.0298 \\
\hline $17-19$ & F. oats .... & A. Beijerinckii _....... & 2.7155 & 2.9924 & 3.3370 & \\
\hline $18-20 \ldots$ & C. oats _..- & A. Beijerinckii _. & 2.6134 & 2.8626 & 3.1866 & \\
\hline $21-23$ & F. clover _... & A. Beijerinckii _- & 3.3343 & 3.6743 & 3.6107 & 0.0636 \\
\hline $22-24 \ldots--$ & C'. elover -...- & A. Beijerinckii _......... & 3.2681 & 3.5857 & 3.4603 & 0.1251 \\
\hline $25-27-\cdots$ & F. oats & A. ringlandii _........... & 2.8032 & 8.1115 & 3.3370 & - \\
\hline $26-28 \ldots$ & C. oats _..... & A. Vinelandii _....... & 2.6936 & 2.9763 & 3.1866 & \\
\hline $29-31$ & F. clover -..-- & A. Vinglandii & 3.3205 & 3.6591 & 3.6107 & 0.0384 \\
\hline $30-32 \ldots$ & C. clover - & 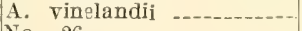 & 3.4 & 3.6322 & 3.4603 & 0.1719 \\
\hline $33-35$ & F. oats -.... & No. 26 , $2, \ldots$ & 2.7547 & 3.0356 & 3.3370 & \\
\hline $34-36 \ldots-\ldots$ & C. oats _..... & No. 26 _. & 2.8912 & 3.1730 & 3.1866 & \\
\hline $37-39 \ldots$ & $\mathrm{F}^{\mathrm{v}}$, clover -- & No. 26 _. & 3.4921 & 92 & 3.6107 & 0.2385 \\
\hline $38-40 \ldots$ & C. clover -..-- & No. $26 \quad \ldots$ & 3.0648 & 3.3747 & 3.4603 & $--n-$ \\
\hline $41--43 \ldots$ & F. oats _..... & No. 27 _. & 2.7015 & 2.9770 & 3.3370 & $--2-2-1$ \\
\hline $42-44 \ldots$ & Cl. oats .... & No. 27 _. & 3.0503 & 3.3129 & 3.1866 & 0.1563 \\
\hline $45-47 \ldots-$ & F. elover -..-- & No. 27 _... & 3.4487 & $3.800 t$ & 3.6107 & 0.1897 \\
\hline $16-48 \ldots$ & C. clover _...- & No. 27 _..... & 3.5059 & 3.8613 & 3.4603 & 0.4010 \\
\hline $49-51 \ldots$ & F. oats & No. 22 - & 2.7083 & 2.9845 & 3.3370 & -......- \\
\hline $50-52 \ldots$ & C. oats & No. 22 _ & 2.8984 & 3.1700 & 3.1866 & \\
\hline $53-5 \overline{5} \ldots \ldots$ & F. elover _.... & No. 22 _. & 3.3977 & 3.7442 & 3.6107 & 0.1335 \\
\hline $51-56 \ldots$ & O. clover =--- & No. 22 & 3.2667 & 3.59251 & 3.4603 & 0.1322 \\
\hline $5 \pi-59 \ldots$ & F. oats ......... & No. 4 ...... & 2.6146 & 2.8812 & 3.3370 & -n-n \\
\hline $58-60 \ldots$ & C. oats ....... & No. 4 ....... & 2.8246 & 3.1202 & 3.1860 & \\
\hline $61-63 \ldots$ & F. clover _... & No. 4 & 3.3998 & 3.7465 & 3.6107 & 0.1358 \\
\hline $62-64$ & C. clover _.... & No. 4 - & 3.1740 & 3.4913 & 3.4603 & 0.0310 \\
\hline $65-67_{-} \ldots$ & $F^{0}$ oats & Mixed culture & 2.5210 & 2.7781 & 3.3370 & --- \\
\hline $66-69_{-}$ & C. oats _....... & Mixed culture ......... & 2.6935 & 2.9310 & 3.1866 & $\ldots$ \\
\hline $69-71$ & $F^{2}$, clover _.... & Mixed culture & 3.2596 & 3.6031 & 3.6107 & \\
\hline $70-72 \ldots$ & C. clover _-.-- & Mixed culture - & 3.3852 & 3.7159 & 3.4603 & 0.2556 \\
\hline $73-74$ & F. nothing --- & Check _... & $2.823 \bar{y}$ & 3.1115 & $\ldots-\infty$ & $+\cdots$ \\
\hline $75-76$ & C. nothing -.- & Check -.....-. & 2.7518 & 3.0537 & $\ldots$ & \\
\hline $77-7 S_{2}-$ & F. nothing $\ldots$ & 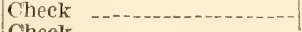 & 2.9758 & 3.2793 & & \\
\hline $79 \mathrm{~s}$ & O. nothing =- & Cheek _. & 2.7736 & 3.0364 & $\ldots$ & \\
\hline
\end{tabular}


growing plants such as clover. In the first class are included $A$. chroococcum $(H C M), A$. beijerinckii, A. vinelandii, No. 27 and the mixed cultures. The first three organisms have had their nitrogen-fixing powers stimulated by the presence of the plants in practically the same ratio and have fixed similar amounts in both the fallow and cropped soil. A. beijerinckii showed the highest fixation of any of the eight for this series. The mixed cultures showed no fixation whatever in the fallow ssils, but quite an appreciable amount in the cropped soils. No. 26, on the contrary, fixed an appreciable amount of nitrogen in the fallow soils but none at all in the presence of the growing oats plants. A. chroococcum and No. 4 showed the same stimulation under practically the same conditions, namely, that they possess a greater nitrogen-fixing power in the presence of decaying clover if no crop is grown upon the soil, while No. 22 was apparently neither stimulated nor retarded by either fallow or cropped conditions, but was affected by the presence of the decaying oats straw.

\section{THIRD GROWING PERIOD.}

The results for this period are shown in appendix table III and condensed table XII. The total nitrogen content of the soil according to tables IX, X and XI, increased steadily through-

TABLE XII-THE NITROGEN FIXATION BY BACTERIA-THIRD PERIOD

(Condensed from Appendix Table III).

\begin{tabular}{|c|c|c|c|c|c|c|c|}
\hline \multirow[b]{2}{*}{ 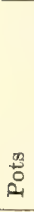 } & \multirow[b]{2}{*}{ Treatment } & \multirow[b]{2}{*}{$\begin{array}{c}\text { Bacterial Inoculum } \\
\text { Used }\end{array}$} & \multicolumn{5}{|c|}{ Grams Nitrogen per 10 Pounds Soil } \\
\hline & & & $\begin{array}{l}\vec{J} \\
\text { z } \\
\text { z }\end{array}$ & 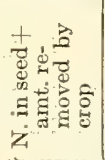 & 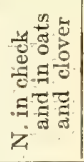 & 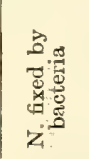 & 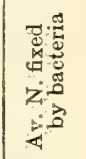 \\
\hline 1 & $F^{\circ} \cap$ & A. chrooc. (HCM) & 2.3626 & 2.8618 & 2.8502 & 0.0146 & \\
\hline 3 & F oats & A. chrooc. (HCM) & 2.7342 & $3.316 \overline{2}$ & -2.8502 & 0.4068 & 0.2405 \\
\hline 2 & C oats & A. chrooc. (HCM) & 2.3643 & 2,0647 & 3.3284 & & \\
\hline 4 & C oats & A. chrooc. ( $\mathrm{HCM})$ & 2.1930 & 2.6754 & 3.3294 & & \\
\hline 5 & F clover & A. chrooc. (HCM) & 2.9255 & 3.5486 & 3.1239 & 0.4247 & \\
\hline 7 & F clover & A. chrooc. ( $\mathrm{HCM})$ & 2.8274 & 3.4296 & 3.1239 & 0.3057 & 0.36 \\
\hline$\dot{0}$ & C clover & A. chrooc. ( $\mathrm{HCM})$ & 3.2852 & 4.0691 & 3.6021 & 0.4670 & \\
\hline 8 & C clover & A. chrooc. ( $\mathrm{HCM})$ & 2.8688 & 3.6142 & 3.6021 & 0.0121 & 0.2395 \\
\hline 9 & F oats & A. Chroococcum & 2.7489 & 3.3344 & 2.8502 & 0.4842 & \\
\hline 11 & F oats & A. Chroococcum & 2.3103 & 2.8024 & 2.8502 & & 0.2421 \\
\hline 10 & O oats & A. Chroococcum. & 2.3652 & 2.9149 & 3.3284 & & \\
\hline 12 & C oats & A. Chroococcum. & 2.3785 & 2.9637 & 3.3284 & & \\
\hline 13 & F clover & A. Chroococcum - & 2.8928 & 3.5089 & 3.1239 & 0.3850 & \\
\hline 15 & F elover & A. Chroococcum & 3.1516 & 3.8265 & 3.1239 & 0.7026 & 0.5438 \\
\hline 14 & C clover - & A, Chroococcum & 2.8489 & 3.5649 & 3.6021 & & \\
\hline 16 & C Clover & A. Chroococcum - & 2.750 & 3.4326 & 3.6021 & & \\
\hline 17 & F oats & A. beijerinckii. & 2.5789 & 3.1279 & 2.8502 & 0.2777 & \\
\hline 19 & F oats & A. beijerinckii & 2.4805 & 3.0088 & 2.8502 & 0.1586 & 0.2182 \\
\hline 18 & $\mathrm{C}^{\prime}$ oats & A. beijerinckii & 2.2943 & 2.8469 & 3.3284 & & \\
\hline 20 & Cl cats & A. beijerinekii & 2.0737 & 2.5764 & 3.3284 & & \\
\hline 21 & $F^{v}$ elover & A. beijerinckii & 3.5203 & 4.2705 & 3.1239 & 1.1466 & \\
\hline 23 & F clover & A. beijerinckii & 3.0368 & 3.6836 & 3.1239 & 0.5597 & 0.8532 \\
\hline
\end{tabular}


TABLE XII-Continued

\begin{tabular}{|c|c|c|c|c|c|c|c|c|}
\hline \multirow[b]{2}{*}{$\stackrel{\infty}{\infty}$} & \multirow{2}{*}{\multicolumn{2}{|c|}{ Treatment }} & \multirow[b]{2}{*}{$\begin{array}{c}\text { Bacterial Inoculum } \\
\text { Used }\end{array}$} & \multicolumn{5}{|c|}{ Grams Nitrogen Per 10 Pounds Soil } \\
\hline & & & & 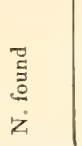 & 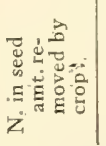 & 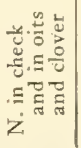 & 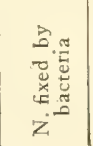 & 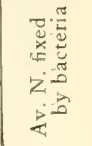 \\
\hline 22 & $\mathrm{C}$ & clover _.-. & A. beijer & & 256 & 3.6021 & & \\
\hline 24 & C & clover & A. beijerinckii & 2.7694 & 581 & 3.6021 & & \\
\hline 25 & $\mathbf{F}$ & oats $\ldots$ & A. vinelandii & 2.5431 & 3.0817 & 2.8502 & 0.2345 & \\
\hline 27 & $F^{*}$ & oats -.. & A. vinelandii..... & 2.4478 & 2.9691 & 2.8502 & 0.1189 & 0.1767 \\
\hline 26 & $\mathrm{C}^{i}$ & oats $=$ & A. vinelandii...-- & 2.3 & 2.9781 & 3.3284 & - & \\
\hline 28 & $\mathrm{C}^{\prime}$ & oats & A. vinelandii & 2.3491 & 2.9491 & 3.3281 & & \\
\hline 29 & $F$ & clover - & A. vinelandii...- & 3.0172 & 3.6598 & 3.1239 & (․ 5359 & \\
\hline 31 & $\mathbf{F}$ & clover -- & A. vinelandii & 11 & 3.7252 & 3.1239 & 0.6013 & 0.5686 \\
\hline 30 & 0 & clover _.....- & A. vinelandii.... & 2.7429 & 3.4284 & 3.6021 & & \\
\hline 32 & C & clover _-....-- & A. vinelandii & 2.7363 & 3959 & 3.6021 & & \\
\hline 33 & $F^{\prime \prime}$ & oats & No. 26 .................. & 2.4609 & 2.9550 & $2.8 \overline{502}$ & $0: 1348$ & \\
\hline 35 & $F$ & oats $\ldots-\ldots--=$ & No. 26 & 2.3 & 2.8857 & 2.8502 & 0.0385 & 0.0862 \\
\hline 34 & $\mathrm{C}$ & oats _....... & No. $26 \ldots$ & 2. & 673 & 3.3284 & & \\
\hline 36 & C & oats .... & Ao. $26 \ldots$ & 2.3321 & 2.9716 & 3.3784 & & \\
\hline 37 & $F^{*}$ & clover -- & $10.25 \ldots$ & 2.9895 & 3.6162 & 3.1239 & 0.4923 & \\
\hline 39 & $\mathbf{F}^{*}$ & clover _...- & No. $26 \ldots$ & 2.0164 & 459 & 3.1239 & & 0.2462 \\
\hline $3 s$ & Cl & clover _..... & No. $26 \ldots$ & 2.7749 & 3.4477 & 3.6021 & & \\
\hline 40 & C & clover & No. $26 \ldots$ & 2.8877 & 3.5388 & 3.6021 & & \\
\hline 41 & $F^{\#}$ & oats & $\mathrm{No}, 27$ & 2.4478 & 691 & 2.8502 & 0.1189 & \\
\hline 43 & $F^{\prime}$ & Oats _. & No, 27 & 2.4871 & 3.0169 & 2.8502 & 0.1667 & $0: 1428$ \\
\hline 42 & C & oats $=--\ldots$ & No. $27 \ldots$ & 2.4583 & 3.0736 & 3.3281 & $--n-\infty$ & - \\
\hline 44 & d & oats & No. 27 & 2.4917 & 595 & 3.3281 & & \\
\hline 45 & $\mathrm{~F}$ & clover _...... & No. 27 & 2.8143 & 3.4137 & 3.1239 & 0.2898 & \\
\hline 47 & E & clover & No. 27 & 3.0564 & 3.7074 & 3.1239 & 0.5835 & 0.4366 \\
\hline 46 & C & clover & $\mathrm{No} \cdot 27 \ldots$ & 3.0181 & 3.7421 & 3.6021 & 0.1100 & \\
\hline 48 & C & clover ......... & No. $27 \ldots$ & 2.8621 & 3.5807 & 3.6021 & & 0.0700 \\
\hline 49 & $F^{n}$ & oats & No. $22 \ldots$ & 2.4961 & 3.0278 & 2.8502 & 0.1776 & \\
\hline 51 & E & oats _....... & No. $2 \mu 2, \ldots$ & 2.2186 & 2.6911 & 2.8502 & $\ldots$ & 0.0888 \\
\hline 50 & $\mathrm{C}^{4}$ & oats $\ldots$ & No. $22 \ldots$ & 2.5580 & 3.1751 & 3.3284 & & \\
\hline 52 & 0 & oats & No. 22 & 2.4451 & 758 & $3.328 t$ & & \\
\hline 53 & F & clover _....... & No. 22 & 2.7230 & 3.3029 & 3.1239 & 0.1790 & \\
\hline 55 & $\mathbf{F}^{0}$ & clover _....... & No. $28 \ldots$ & 2.8667 & 3.4773 & 3.1239 & 0.3534 & 0.2662 \\
\hline 54 & C & clover . =- & No. 22 _. & 2.7893 & 3.5060 & 3.6021 & -- & $\ldots$ \\
\hline 56 & $\mathrm{C}$ & clover -- & No. 22 & 2.6236 & 3.2953 & 3.6021 & & - \\
\hline 57 & F & oats _... & No. 4 - & 2.3 & 2.8321 & 2.8502 & & \\
\hline 59 & F & cats & No. 4 & 2.4094 & 2.9126 & 2.8502 & 0.0624 & 0.0312 \\
\hline 58 & $\mathrm{O}$ & Oits $\ldots$ & No. $4 \ldots$ & 2.3170 & 2.8056 & 3.3281 & -- & $\ldots$ \\
\hline 60 & $\mathrm{C}^{y}$ & $\operatorname{cats}$ & No. 4 & 2.6037 & 3.3103 & 3.3284 & & \\
\hline 61 & F & clover _. & No. 4 & 3.0173 & 3.6599 & 3.1239 & 0.5360 & \\
\hline 63 & F & clover _...--- & No. 4 & 2.8208 & 3.4216 & 3.1 & 0.2977 & 0.4168 \\
\hline 62 & a & clover & No. \& & 2.8877 & 3.6172 & 3.6 & 0.0151 & \\
\hline 64 & $\mathrm{Cl}$ & Clover -- & No. is & 2.8224 & 3.5098 & 3.6021 & - & 0.0076 \\
\hline 65 & F & oats & Mixed cilture -- & 2.3496 & 2.8501 & 2.8502 & & $\ldots$ \\
\hline 67 & $F$ & oats $\ldots$ & Mixed culture -...... & 2.3234 & 2.8183 & 2.8502 & & $-\ldots$ \\
\hline 66 & 0 & oats _....... & Mixed culture & 2.4381 & 3.0435 & 3.3281 & & \\
\hline 68 & $C^{\prime}$ & oats $\ldots$ & Mixed culture & 2.3586 & 37 & & & \\
\hline 69 & F & elover _..._. & Mixed culture ...... & 3.0761 & 3.7313 & 3.1239 & 0.6074 & \\
\hline 71 & $\mathrm{~F}^{n}$ & clover . . - & Mixed culture & 2.7831 & 3.3759 & 3.1 & 0.2520 & 0.4297 \\
\hline 70 & C & clover _...... & Mixed eulture -...... & 2.8366 & & 3. & 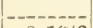 & $-\ldots$ \\
\hline 72 & $\mathrm{C}$ & clover _....... & Mixed cliture ...... & 3.0306 & 3.7664 & 3.6021 & 0.1643 & 0.08262 \\
\hline 73 & $\mathbf{F}$ & nothing & Check _. & 2.3216 & 2.8161 & * & $*$ & * \\
\hline 74 & $F^{\prime}$ & nothing & Check & 2.0944 & 2.5405 & * & $*$ & * \\
\hline 77 & $F$ & nothing -.--- & Check & $2.107 a$ & 2.5563 & * & * & * \\
\hline 78 & $F$ & nothing _.... & Check & $2: 4085$ & 2.9215 & $*$ & * & * \\
\hline 75 & $\mathrm{O}$ & nothing - & Check & $2: 7760$ & 3.3649 & if & $t$ & $\dagger$ \\
\hline 76 & $\mathrm{C}^{\mathrm{t}}$ & nothing - - & Check - & 2.5375 & 3.1041 & + & $\dagger$ & t \\
\hline 79 & $\mathrm{C}^{i}$ & nothing -..-- & Oheck & 2.4911 & 3.1522 & $t$ & $t$ & $\dagger$ \\
\hline so & $\mathrm{C}$ & nothing & Check & 2.4901 & 3.1362 & $\dagger$ & + & $t$ \\
\hline
\end{tabular}

*Average four fallow checks 2.7086.

tAverage four eropped checks 3.1868. 
out the first growing period, declined somewhat during the second, and according to table XII, there was a pronounced tendency to increase again during the third period. The crop response of this last period of growth confirms the results of the determinations, the amount of dry matter produced being practically midway between the production of the first and second growing periods. Figs. 1-6, which show the growth of oats in representative pots for the three periods, show that the first crop when ready to harvest was in the majority of cases leafy and heavy and showed a decided tendency to lodge; the second crop in the same stage of growth was somewhat dwarfed in appearance and with no indication of leafiness or weakness of stem; the third crop, while not as heavy as the first, showed all of its characteristies except that as a whole the production was more uniform and did not show the variation in the total dry weight of the harvested crop. The bacterial activities, which are plotted in the tables shown in fig. 7 , varied in the same proportion as the crop response of the treated soils, being practically parallel with the production of the dried weight of the erop. The activities increased during the first growing period, declined thruoult the second, but increased again during the third. The discussion of the third and last period of growth will be a combination of the activities of the inoculated bacteria as discussed in the first and second growing periods.

The last column in table XII indicates that each inoculated bacterial culture acted without exception in the same general manner instead of showing the expected variations. All of the inoculated bacteria fixed greater amounts of nitrogen in the soils to which clover hay was added as organic matter than in soils that were treated with the same amount of oats straw, and the growing crop on these soils reduced the nitrogen-fixing power of each and every one of these organisms. The activities of any one of the eight organisms used during the third period of growth would be an accurate measure for the activities of any of the others, a fact not even indicated in the other periods of growth.

Conclusion: Table XIII, recapitulating tables X, XI and XII, shows that inoculation, especially in fallow soils to which clover hay or oats straw was added, is not only possible but practical. The amounts of nitrogen shown in these tables are the actual amounts fixed by the organisms in ten pounds of soil and if these amounts are calculated on a 2,000,000 pound acre basis, the result is distinctly profitable. With proper soil conditions the greenhouse experiments can be duplicated in the field.

All of the organisms have shown an appreciable fixation of nitrogen but $\mathrm{A}$. beijerinckii and $\mathrm{A}$. vinelandii have been decidedly the most active. This finding confirms the suggestion of 


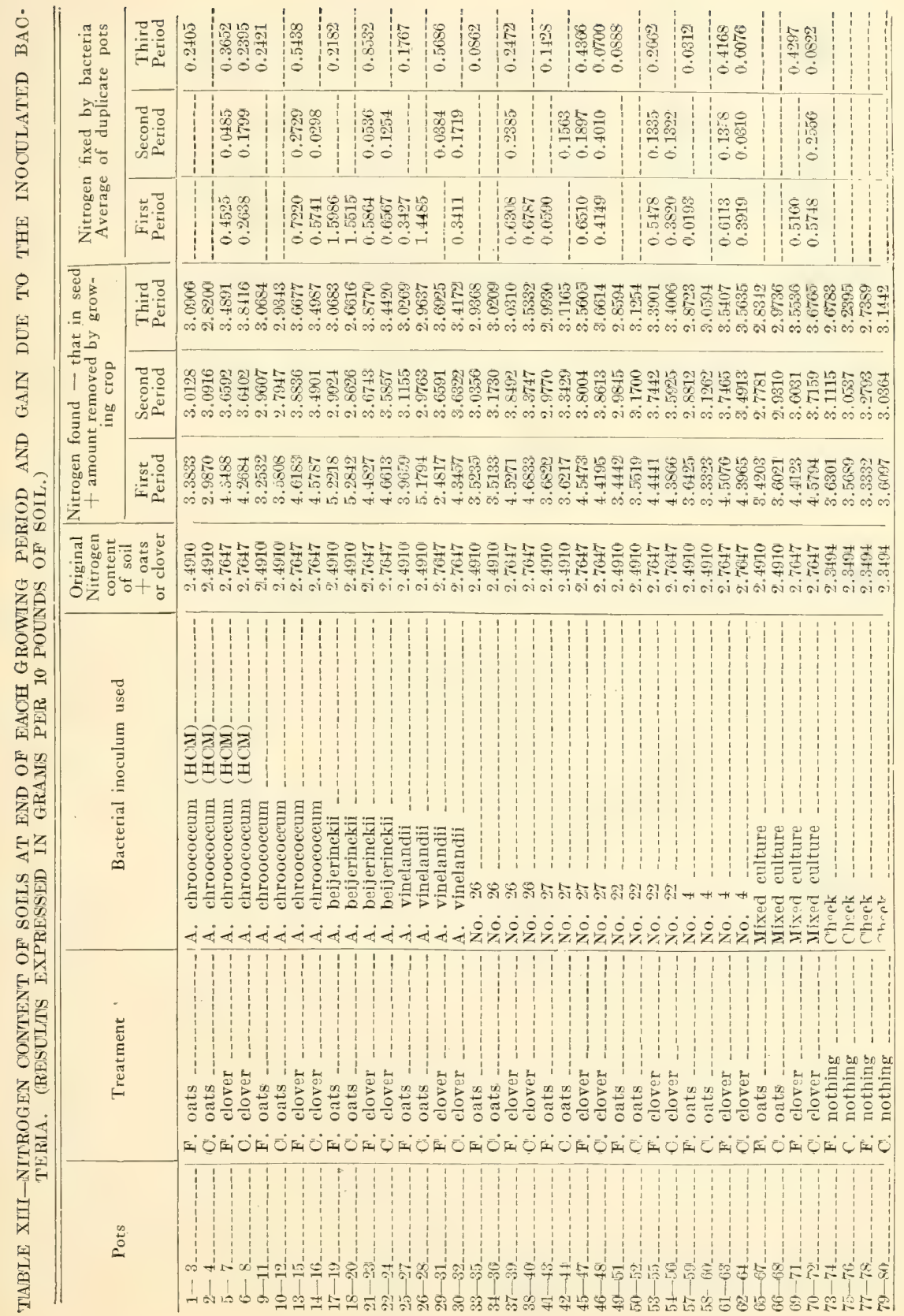




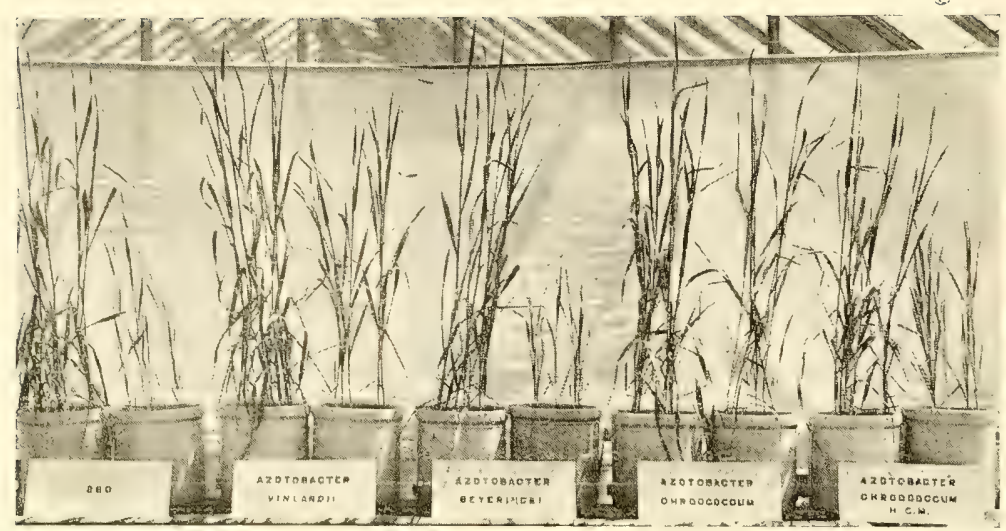

Fig. 1. Oats at ènd of first growing period, immediatèly before hàrvèst; in pots $2,6,10,14,18,22$ $26,30,24,38$

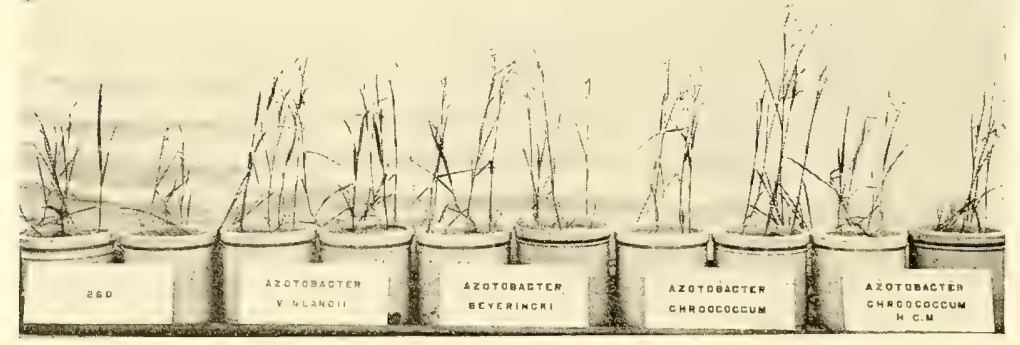

FIG. 2. Oats at end of first growing period, mmediately before harvest; pots $44,48,52,56,60,64$, $68,72,76,80$

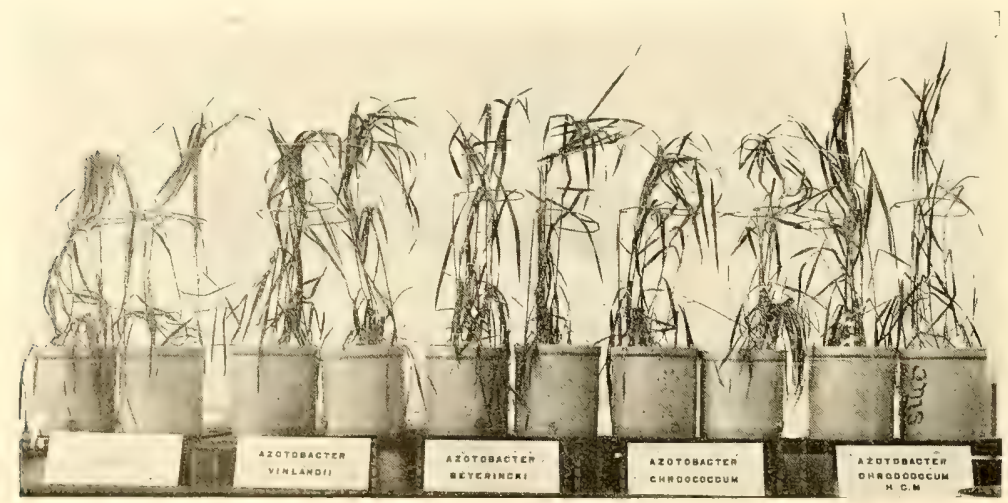

FIG 3. Oats at end of second growing period; immediately before harvest; pots $2,6,10,14,18,22$, $2630,34,38$ 


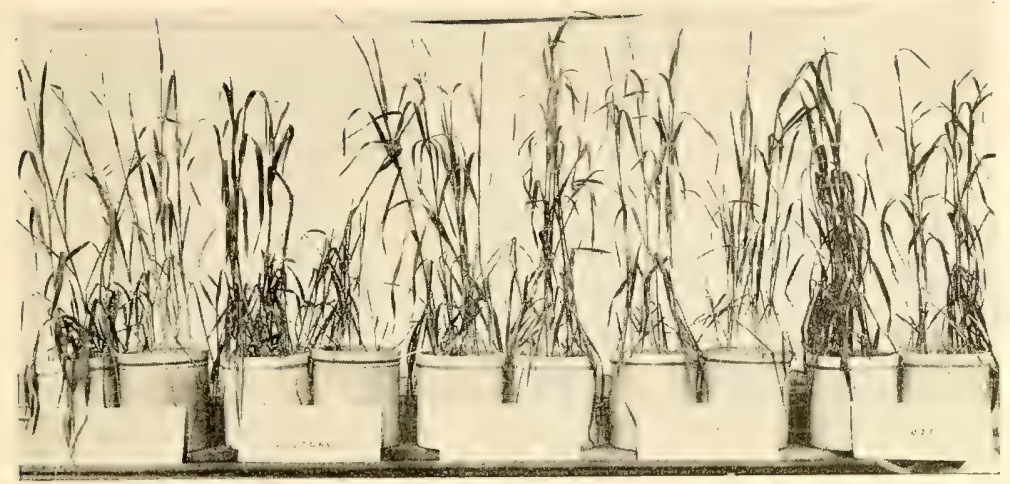

FIG. 4. Oats at end of second growing period, immediately before narvest; pots $42,46,50,54,58$. $62,66,70,75,79$

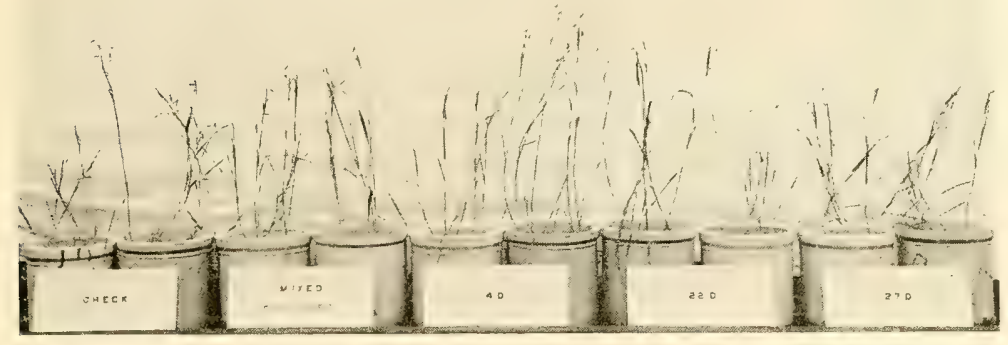

IG. 5. Oats at end of third growing period, mmediately before harvest; pots 4, 8, 12, 16, 2024 , $28,32,36,40$

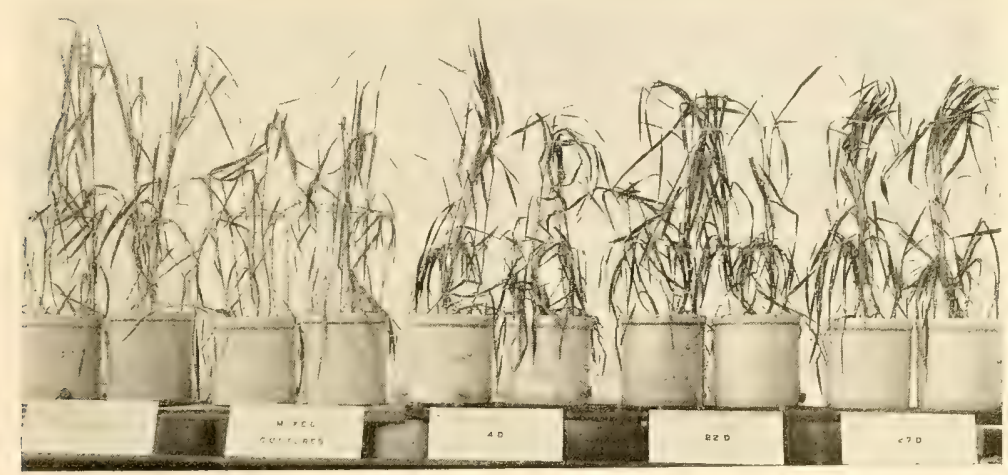

FIG. 6. Oats at end of third growing period, immediately before harvest; pots 44 48, 52, 5660 $64,68,72,76,80$ 


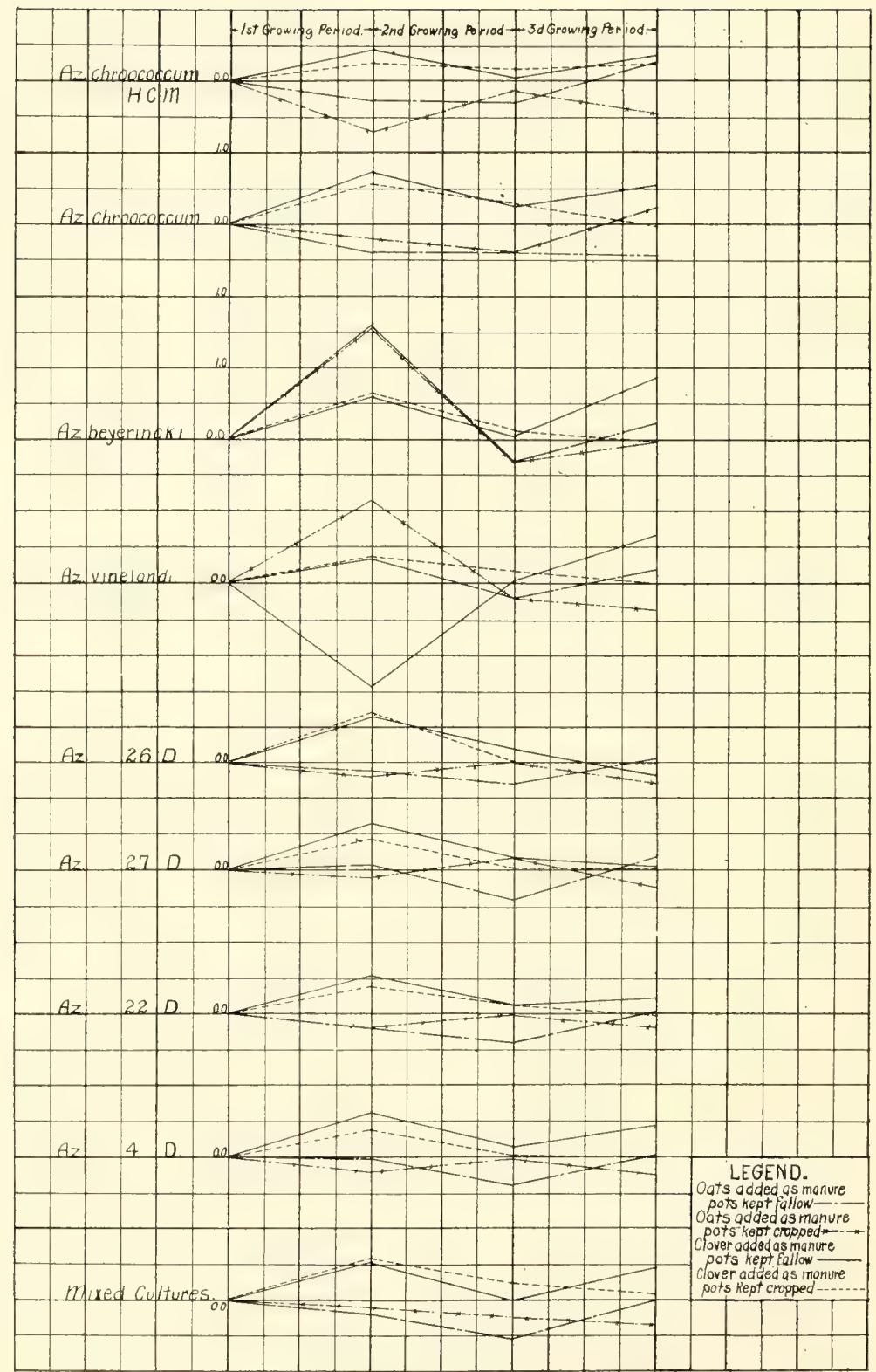

FIG. 7. This graph shows the variation in bacterial activity in the different growing periods 
Lipman and Brown (41) by proving definitely that these organisms are capable of being profitably inoculated into field soils, provided that organic matter, earrying a sufficient amount of nitrogen as a stimulus, is supplied.

\section{Summary.}

1. When three crops of oats were grown continuously on this soil the nitrogen content of the soil increased during the first cropping period, decreased during the second, and increased slightly again during the third.

2. The nitrogen-fixing powers of the bacteria and the crop response were parallel with the total nitrogen content of the soil.

3. The nitrogen-fixing powers of some types of azotobacter and other large celled organisms of the same general character, were stimulated to a greater extent by the presence of decaying clover hay than of decaying oats straw.

4. The nitrogen-fixing powers of $A$. beijerinckii and $A$. vinelandii were stimulated to a greater extent by decaying oats straw than by elover hay, especially during the earlier stages of decomposition.

5. The nitrogen-fixing powers of the azotobacter and other large celled organisms of the same general type eventually became greater in fallow than in eropped soils.

6. The non-symbiotic nitrogen-fixing organisms of the azotobacter group were all eventually influenced in their activities in the same manner and by the same materials.

7. Soils may be profitably inoculated by azotobacter and other large celled organisms of the same type, the best effects being secured in this work by an inoculation with $A$. beijerinckii or A. vinelandii.

8. The conditions necessary for the greatest fixation are: Good environmental factors such as tillage, drainage, ete.; the presence of a rapidly decaying organic matter carrying a small nitrogen content, and freedom from growing plants.

\section{ACID EXTRACT, AMINO, NON-PROTEIN AND POLYPEP- TID NITROGEN CONTENT OF THE POT SOILS.}

Introduction: The nitrogen of the soil is found in many complex combinations, in the determination of which the Bureau of Soils has isolated a large number of nitrogenous compounds and many different forms have been discovered. In investigating methods for the determination of amino acids and nitrates in a limed and unlimed soil, both with and without heavy applications of manures, Potter and Snyder (53) have found that they could accurately measure the amino nitrogen by a modification of the method devised by Kober and Sugiura (32). They discovered 
no tendency for the amino acid to accumulate under the conditions of the experiment. Accordingly in the present investigation determinations were made of the acid extract, non-protein, amino, and polypeptid nitrogen of some of the soils inoculated with the azotobacter cultures used in the greenhouse experiments, in order to prove this point and also to discover if the bacterial action had any effect on the accumulation or disappearance of these nitrogenous forms.

Soils used: Only the three soils inoculated with A. chroococcum, A. beijerinckii and $A$. vinelandii were analyzed.

\section{METHODS.}

Acid extract: Place $166 \mathrm{gr}$. of air dried soil on a wetted double filter paper in a Buchner funnel and extract with 600 c. c. of a $1 \% \mathrm{HC1}$ solution using gentle suction. Keep the soil barely covered with the solution and when extracted, wash with 200 to 300 c. c. of pure distilled water. Dry as quickly as possible, and determine the nitrogen content of the filtrate by the official salicylic acid method.

Alkali extract: The non-protein, amino, and polypeptid nitrogen determinations are based on the amounts extracted by a $1.5 \% \mathrm{NaOH}$ solution. Shake $150 \mathrm{gr}$. of the air dried acid extracted soil with 600 c. c. of the $\mathrm{NaOH}$ solution and centrifuge to a clear solution. At least 210 c. c. cf the clear solution must be obtained.

Non-protein nitrogen: Pipette off 25 c. c. of the alkali extract, neutralize with a sulphuric acid solution and add sufficient trichloracetic acid to make a $2.5 \%$ solution. To do this use $4.3 \mathrm{c}$. e., of a $13 / 10 \mathrm{~N} \cdot \mathrm{H}_{2} \mathrm{SO}_{4}$ solution and 0.75 e. e. of a saturated trichloracetic solution. This method precipitates the proteins which are removed by filtering. Pipette 10 c. c. of the elear filtrate into large test tubes, add a couple glass beads, 2 drops of a $5 \%$ $\mathrm{CuSO}_{4}$ solution, 1 c. c. C. $\mathrm{P} . \mathrm{H}_{2} \mathrm{SO}_{4}$, and approximately 1 gr. C. P. potassium sulfate. Digest and distil as in the regular Kjeldahl method determining the ammonia colorimetrically.

Amino acid nitrogen: Pipette 80 c. c. of the alkali extract into 100 œ. e. measuring flasks, neutralize with strong HC1 until neutral to litmus, add 7 c. c. saturated lead acetate solution, fill the flask to the mark with concentrated $\mathrm{NH}_{4} \mathrm{OH}$ and shake vigorouly. Allow to settle for a few minutes then pass through double filter, using gentle suction and obtain at least 80 c. c. of the filtrate. Measure off 75 c. c. of this filtrate, add 25 c. c. saturated $\mathrm{Ba}(\mathrm{OH})_{2}$ and phenolphthalein as indicator and distill over steam bath under reduced pressure until there remains a volume of about 25 or 30 e. e. It is important that the reaction of the solution throughout this distillation should be at all times 
alkaline. Discard the distillate, wash residue into 100 c. c. graduate, cool, make up to 75 c. c., filter quickly to remove all carbonates, pipette 50 c. c. into 100 c. c. measuring flasks, make approximately neutral with $\mathrm{N} / 10 \mathrm{HC} 1$ and add 40 c. c. of butfer solution, stopper tightly and keep in cool place, if possible, on ice. (The buffer is made by dissolving $0.2 \mathrm{gr}$. molecules of boric acid in water, adding 100 c. c. of $\mathrm{CO}_{2}$ free $\mathrm{N} / 10 \mathrm{NaOH}$ solution and making up to $1000 \mathrm{c}$. c. with pure $\mathrm{CO}_{2}$ free water. Three volumes of this mixed with one volume of $\mathrm{O} / 1 / \mathrm{N} \mathrm{HC} 1$ makes the desired solution.)

Use pure water as cold as possible to prepare fresh the following solution: Place $10-20 \%$ copper chloride solution in $20-30$ volumes cold water, add a few drops phenolphthalein and a saturated solution $\mathrm{Ba}(\mathrm{OH})_{2}$ until the purple color just forms. Centrifuge, decant off the clear liquid, wash with cold water and recentrifuge, repeating until there is no pink color formed by the addition of phenolphthalein in the wash water. Suspend the copper hydroxide in about $100 \mathrm{c}$. c. cold water and add approximately 1 . c. c. to the cool flasks, shake vigorously, make up to the mark, and allow to warm up to the room temperature. Filter through No. 589 blue ribbon filter, pipette off 50 c. c. of the filtrate and determine the copper complex present as shown below as a measure of the amino nitrogen. Pipette off 40 c. c. of the filtrate for the determination of the polypeptid nitrogen.

Polypeptid nitrogen: Hydrolize the polypeptids into amino acids by adding approximately 5 c. c. concentrated $\mathrm{H}_{2} \mathrm{SO}_{4}$ to the 40 e. c. and placing under a steam pressure of $8-10$ pounds for 10-12 hours. Remove the excess acid with a saturated solution $\mathrm{Ba}(\mathrm{OH})_{2}$ keeping the solution slightly alkaline to phenolphthalein, filter and wash with carbonated water at least three times. Evaporate the filtrate to about 35 or 40 c. c., place in 100 c. c. measuring flasks, neutralize with $\mathrm{N} / 10 \mathrm{HC} 1$, add 40 e. c. buffer solution, 1 e. c. of the copper hydroxide solution in the cold water as for the amino determinations and determine the copper present in the same manner.

Copper determination: Place the beakers containing the 50 c. c. on the hot plate, heat to boiling and neutralize with dilute $\mathrm{HNO}_{3}$. Boil down to about one-half and add bromine water until a decided bromine color appears, evaporate to about 10-15 c. c., add 20-30 c. c. pure water and a little more bromine water and evaporate down again to 10-15 c. c. Cool, add 2-3 c. с. glacial acetic acid, a few crystals potassium iodide, a few drops of starch solution and titrate immediately with .001/ $\mathrm{N}$ sodium thio-sulfate until the blue color disappears. Each c. c. of the $.001 / \mathrm{N}$ thio-sulfate solution is the equivalent of $0.000028 \mathrm{gr}$, amino acid nitrogen. 
Preliminary determinations: In addition to the work on the soils, an unsuccessful attempt was made to determine the amount of non-protein and amino acid nitrogen fixed by the baster:a inoculated into the dextrose solution used in the other experiments. 250 e. c. of the dextrose solution was inoculated with the organisms indicated in Table 14 and incubated three weeks at room temperature. Enough e. p. sodium hydroxide was added directly to the solution to make $1.5 \%$ and the determination carried out in the above manner. A slight trace was the greatest amount found.

This table shows a decided increase in the soils under field conditions over the same soils in the dry state, the greatest increase taking place during the earlier periods of growth. The results of these determinations are grouped in three tables, each showing the amount of the different nitrogenous forms found at the end of each growing period.

Discussion of results: A comparison of the results given in Tables XVI, XVII and XVIII, shows that there was a definite variation of the nitrogenous forms with the length of the time of cropping. In almost every case the amount extracted by the acid varied with the length of time that the soil had been cropped, growing smaller and smaller, and the amino and polypeptid nitrogen gave similar results. The amount of these nitrogenous

TABLE XIV-AMINO ACID AND NON-PROTEIN NITROGEN FIXED BY THE PURE CULTURES IN SIOLUTION.

\begin{tabular}{|c|c|c|c|c|}
\hline $\begin{array}{l}\frac{x}{m} \\
\frac{\pi}{a}\end{array}$ & & Inoculum & Non-protein N. & Amino Acid $\mathrm{N}$. \\
\hline 1 & A. chroococcum & $(\mathrm{HCl} \mathbf{M})_{-}$ & --- & trace \\
\hline 2 & A. chroococeum & $(\mathrm{HC} / \mathrm{MI})_{-}$ & 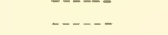 & $\ldots$ \\
\hline 3 & A. ehroococcum & $(\mathrm{HOLM}) \ldots$ & -..- & 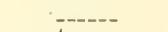 \\
\hline 4 & No. 26 - & (-non & $-\ldots+n$ & tracs \\
\hline $\begin{array}{l}5 \\
6\end{array}$ & No. 26 - & - n & traco & $-\cdots-$ \\
\hline 7 & A. chroococeum & (HOM) and No. 26 & traco & trace \\
\hline 8 & A. chroococcum & $(\mathrm{H} \mid \mathrm{CM})$ and No. $26 \ldots$ & - - & trace \\
\hline 9 & A. chroococeum & (HCMI) and No. 26 & $\ldots$ & $\ldots$ \\
\hline
\end{tabular}

TMBLE XV-THE: AMOUNT OF DIF"FEREN" NITROGENOUS FORMS IN THE SOIL AT 'THE BEGINNING OF "THE EXPERLMENTS, ALSO THE SAIIE SOII PLUS "IHE" EQUIVALENT OF" FIVE TONS GROUND OATS, STRAIV OR GIOUND CLOVER HLY ADIDED TO THE SAMPLE. DETERMINATIONS BASED ON THE AMOUNT TN 25 GIR. OIF THIE SAMPLE AND RIESULT'S FXPIRIESISED IN MG. NITROGEN AND IN PER CENT OF THE TOTAL NITROGEN.

\begin{tabular}{|c|c|c|c|c|c|c|c|c|c|}
\hline Soil & 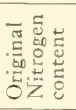 & 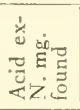 & 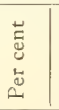 & 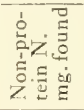 & 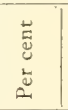 & 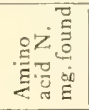 & 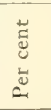 & 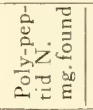 & 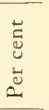 \\
\hline $\begin{array}{l}\text { Original } \\
\text { Original + oats } \\
\text { Original + r£d } \\
\quad \text { clover hay }\end{array}$ & $\begin{array}{l}12.95 \\
12.75\end{array}$ & $\begin{array}{l}1.1242 \\
1.1666 \\
1.4424\end{array}$ & $\begin{array}{l}8.7 \\
8.5 \\
9.3\end{array}$ & $\begin{array}{l}2.2275 \\
2.3390 \\
2.3475\end{array}$ & $\begin{array}{l}17.2 \\
17.0 \\
15.2\end{array}$ & $\begin{array}{l}0.0540 \\
0.1025 \\
0.1050\end{array}$ & $\begin{array}{l}0.7 \\
0.7 \\
0.7\end{array}$ & $\begin{array}{l}0.2100 \\
0.2550 \\
0.2625\end{array}$ & $\begin{array}{l}1.6 \\
1.8 \\
1.7\end{array}$ \\
\hline
\end{tabular}


TABLE XVI-AMIOUNTS OF" THE DIF"FERENT FORLIS OF" NITROGEN IN THE CROPPED AND FALLOW IXOCULATED SOLLS AT THE END OF 'THE FIRST' PERTOD OF GROW'I"H. RESULIS EXPIRESSED IN MG. NITROGEN FOUND AND IN PER CENT' OF' THE 'TOTAL NITROGEN CONTENT, BASED ON 25 GR. SALPLE.

\begin{tabular}{|c|c|c|c|c|c|c|c|c|c|}
\hline Pots & 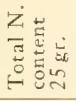 & 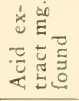 & 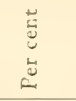 & 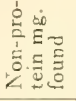 & 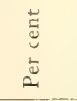 & 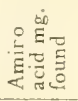 & $\begin{array}{l}\vec{\Xi} \\
\stackrel{\Xi}{0} \\
2\end{array}$ & 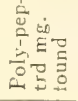 & 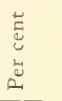 \\
\hline $9-11$ & 14.35 & 2.0242 & $14.1+$ & 3.1675 & 22.0 & 0.1260 & $0.8+$ & 0.4725 & $3.2+$ \\
\hline $10-12$ & $15.60^{\circ}$ & 1.9181 & $12.3-$ & 2.6600 & $17.0+$ & 0.1505 & $0.9+$ & 0.2975 & 1.9 \\
\hline $13-15$ & 20.39 & 2.2151 & $10.8+$ & 2.3690 & $11.6+$ & 0.1400 & $0.7-$ & $0.4 \overline{50}$ & $2.2+$ \\
\hline $14-16_{\ldots}$ & 19.81 & 1.9818 & $10.0+$ & 3.0650 & $15.4+$ & 0.1085 & $0.5+$ & 0.2000 & $1.0+$ \\
\hline $17-19$ & 23.03 & 2.2939 & $9.9+$ & 3.5000 & $15.2+$ & 0.1015 & $0.4+$ & 0.2625 & $1.1+$ \\
\hline $18-20$ & 23.09 & 1.1121 & $4.7+$ & 2.8500 & $12.3+$ & 0.1680 & $0.7+$ & 0.2760 & $0.9+$ \\
\hline $21-23$ & 19.77 & 2.3424 & $11.8+$ & 2.7175 & $13.8-$ & 0.2310 & $1.1+$ & 0.4200 & $2.1+$ \\
\hline $22-2 t$ & 20.19 & 0.9548 & $4.8+$ & 2.7325 & $13.5+$ & 0.1400 & $0.7-$ & 0.3500 & $1.7+$ \\
\hline $25-27$ & 17.50 & 2.44 & $13.7+$ & 2.6950 & 15.4 & 0.1820 & $1.0+$ & 0.4370 & 2.5 \\
\hline $26-28=$ & 22.54 & 1.9878 & $8.8+$ & 2.7425 & $12.11+$ & 0.2110 & $0.9+$ & 0.3150 & $1.4-$ \\
\hline $29-31$ & 20.91 & 2.3848 & 11.4 - & 2.5150 & $12.0+$ & 0.1750 & $0.8+$ & 0.2100 & 1.0 \\
\hline $30-32$ & 18.69 & 0.7515 & $4.1-$ & $2.587 \bar{\vdots}$ & $13.8+$ & 0.0980 & $0.5+$ & 0.3200 & $1.7+$ \\
\hline
\end{tabular}

TABLE XVIT-AMOUNTS OF THE DIFEERENT FOIRMS OF NITROGEN IN THE FALLOW AND OROPPED INOCULATED SOILS AT THE END OF' THE SECOND GROTVING PERIOD, RESULTS EXPRESSED TN MG, N, FOUND AND IN PER CENT" OF" "THE TOTAL N. CONTENT ELASED ON 25 GRAM SAMPLE.

\begin{tabular}{|c|c|c|c|c|c|c|c|c|c|}
\hline Pots & 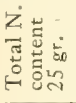 & 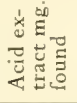 & 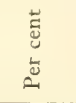 & 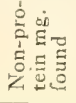 & $\begin{array}{l}\vec{E} \\
\dot{U} \\
\dot{U} \\
\text { a }\end{array}$ & 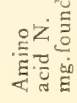 & 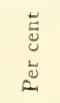 & 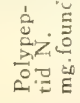 & 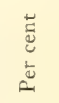 \\
\hline $9-1 \mathrm{~L}_{-}$ & 16.45 & 1.6515 & 10.0 & 1.8375 & $11.1+$ & 0.0700 & $0.4+$ & 0.2800 & $1.7+$ \\
\hline $10-12$ & 15.44 & lost & & 3.4150 & $22.1+$ & 0.1110 & $0.7+$ & 0.3675 & $4-$ \\
\hline $13-15=$ & 21.48 & 2.1896 & 10.2 & 2.0700 & $9.6+$ & 0.1260 & $0.6-$ & 0.1600 & $0.7+$ \\
\hline $14-16$ & 19.32 & 0.7257 & $3.7+$ & 2.9925 & $15 . \overline{5}$ & 0.1400 & $0.7+$ & 0.1225 & $0.6+$ \\
\hline $17-19$ & 16.62 & 0.9212 & $5.5+$ & 2.6825 & $16.1+$ & 0.4750 & $2.8+$ & 0.1750 & $1.1-$ \\
\hline $78-20$ & 15.84 & 0.7257 & $4.6-$ & 3.4075 & $21.5+$ & 0.0201 & $0.1+$ & 0.3500 & $2.2+$ \\
\hline $21-23$ & $19.7 \pm$ & 1.7895 & $9.1-$ & 3.5000 & $17.8-$ & 0.1190 & $0.6-$ & 0.2100 & $1.0+$ \\
\hline $22-24$ & 19.78 & 0.7500 & $3.8-$ & 3.3350 & $16.8+$ & 0.0630 & $0.3+$ & 0.2800 & $1.4+$ \\
\hline $25-27$ & 17.28 & 1.4727 & $8.5+$ & 2.6370 & $15.3-$ & 0.2660 & $1.5+$ & 0.2100 & $1.2+$ \\
\hline $26-28$ & 16.32 & 0.6030 & $3.7-$ & 2.6000 & $15.9+$ & 0.0630 & $0.4-$ & 0.2975 & $1.8+$ \\
\hline $29-31$ & 20.31 & 2.1363 & $10.5+$ & 2.8350 & $13.9+$ & 0.0910 & $0.4+$ & 0.2800 & $1.3+$ \\
\hline $30-32$ & 20.630 & 1.1000 & $5.4+$ & 3.4000 & $16.0-$ & 0.0700 & $0.3+$ & 0.2275 & $1.1+$ \\
\hline
\end{tabular}

TABLE XVIIT-AMOUNTSS OF" THE DIFFERENT FORMS OF" NITROGEN IN THE FALLOW AND CROPPED TNOCULATED SOILS AT THE END OF THE THIRD AND LAST GROWING PERIOD. REISULTS IBASED ON 25 GRIAM SIMPILE, EXPREISSED IN MG. N. FOUND LAND IN PER OENT OF TOTAL N. CONTENT.

\begin{tabular}{|c|c|c|c|c|c|c|c|c|c|}
\hline Pots & 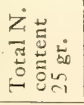 & 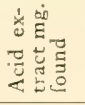 & $\begin{array}{c}0 \\
\bar{u} \\
\vdots \\
\vdots \\
0\end{array}$ & 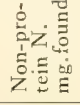 & 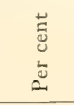 & 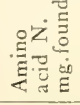 & $\begin{array}{l}\vec{E} \\
\stackrel{u}{u} \\
\end{array}$ & 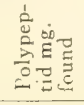 & 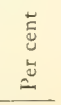 \\
\hline $9-11$ & 16.93 & 1.2833 & $7.5+$ & 2.1475 & $12.7-$ & $0.0 \pm 20$ & $0.2+$ & $0.2 \geq 75$ & $1.3+$ \\
\hline $10-12$ & 15.65 & 0.5773 & $3.7-$ & 3.2850 & $20.9+$ & 0.0490 & $0.5+$ & 0.2100 & $1.3+$ \\
\hline $13-15$ & 20.23 & 0.7485 & $3.7-$ & 2.3675 & $11.2+$ & 0.0420 & $0.2+$ & 0.2450 & $1.2+$ \\
\hline $14-16$ & 18.19 & 0.6306 & $3.4+$ & 3.3005 & $18.1+$ & 0.0910 & $0.4 T$ & 0.2100 & $1.1+$ \\
\hline $17-19$ & 16.90 & 1.1773 & $6.9+$ & 2.7025 & $15.9+$ & 0.021 .0 & $0.1+$ & 0.2625 & $1.6-$ \\
\hline $18-20$ & 14.94 & 0.5560 & $3.7+$ & 3.6825 & 24.7 - & 0.0630 & $0.4+$ & 0.1400 & $0.9+$ \\
\hline $21-23$ & 22.03 & 1.7 & $8.1-$ & 2.8560 & $12.9+$ & 0.0420 & $0.2-$ & 9.2800 & $1.3-$ \\
\hline $22-24$ & 18.21 & 0.7000 & $3.8+$ & 3.0300 & $16.5+$ & 0.3240 & $1.8-$ & 0.1750 & $0.9+$ \\
\hline $25-27$ & 16.71 & 1.5060 & $9.0+$ & 2.6925 & $16.1+$ & 0.0350 & $0.2+$ & 0.5950 & $3.6-$ \\
\hline $26-28$ & 15.66 & 0.7 & $4.6+$ & 3.6350 & $23.2+$ & 0.0420 & $0.3-$ & 0.3150 & $2.0+$ \\
\hline $29-31=$ & 20.36 & 2.2060 & $10.8+$ & 2.7400 & $13.4+$ & 0.0560 & $0.4+$ & 0.7075 & $3.4+$ \\
\hline $30-32 \ldots$ & 18.091 & 0.5929 & $3.3-$ & 3.4500 & $11.3-$ & 0.0770 & $0.4+$ & 0.2800 & $1.5+$ \\
\hline
\end{tabular}


compounds became smaller, as decomposition of the organic matter proceeded, at a slightly faster rate than the total nitrogen content of the soil became depleted. The non-protein nitrogen also varied considerably, altho not in the marked degree shown by the other forms. Neither the oats straw or the red clover hay, added as manures to the pots, showed any effect on the forms of nitrogen determined, further than the small amount shown in the preliminary determinations. If there was a difference in the soil under field conditions it evidently was too small to be measured by these methods. It is entirely possible that the amounts of these complex nitrogenous compounds are rapidly changing into other forms and that the per cent they bear to the total nitrogen content remains somewhat constant, varying only with the amount of organic matter present in the beginning, then as decomposition proceeds and the more complex combinations are broken up, this pereentage relation becomes smaller and smaller until it reaches a constant.

Once decomposition had begun in the soil there was absolutely no tendeney for the more complex nitrogenous forms to accumulate under conditions apprcximating those in the field. Instead of an accumulation there was a steady reduction. How elosely this reduction is coupled with the decay of the organic matter and what would be the final equilibrium between the total nitrogen content and the nitrogenous compounds are questions for further study.

\section{Summary.}

1. The acid extracted, non-protein, amino and polypeptid nitrogen changed into other forms with the advance of decomposition much faster than the total nitrogen contents of the soils in question decreased.

2. Oats straw and clover hay added as manures at the rate of five tons per acre had little effect in influencing this change.

3. The amounts of non-protein and amino acid nitrogen fixed by bacterial eultures in solution were negligible.

4. Bacterial inoculation had apparently no effect on the amounts of non-protein, amino or polypeptid nitrogen in the soil.

5. There was no tendency for the above forms of nitrogen to accumulate in the soil under conditions approximating those in the field.

Acknowledgments: I wish to express my thanks to Dr. P. E. Brown for his help and suggestions thruout this work and to Dr. R. S. Potter for his suggestions in the determinations of the complex forms of nitrogen. 

APPENDIX TABLE II.

\begin{tabular}{|c|c|c|c|c|c|c|c|c|c|c|c|c|c|}
\hline \multirow{3}{*}{$\begin{array}{l}\text { Incoulum Ebed and } \\
\text { Pot No. }\end{array}$} & \multirow{3}{*}{ 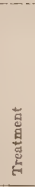 } & \multirow{3}{*}{$\begin{array}{c}\text { Kind of Crop } \\
\text { Grown }\end{array}$} & \multicolumn{5}{|c|}{ 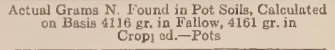 } & \multirow{3}{*}{ 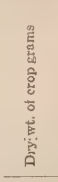 } & \multirow{3}{*}{ 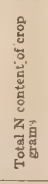 } & \multirow{3}{*}{ 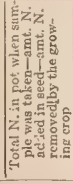 } & \multirow{3}{*}{ 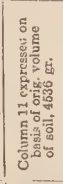 } & \multirow{3}{*}{ 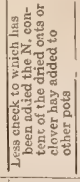 } & \multirow{3}{*}{ 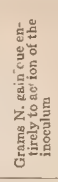 } \\
\hline & & & \multicolumn{3}{|c|}{ Deternination } & \multirow{2}{*}{ 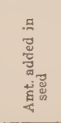 } & \multirow{2}{*}{ 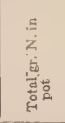 } & & & & & & \\
\hline & & & $\frac{50}{5}$ & 言 & $\rightleftarrows$ & & & & & & & & \\
\hline chrooc. (H) & \multirow[b]{2}{*}{$\mathrm{O}$} & \multirow[b]{2}{*}{$\mid$} & \multirow{3}{*}{$\begin{array}{r}2.737 \\
2.8577 \\
3.385 \\
3.1607\end{array}$} & \multirow{3}{*}{$\begin{array}{l}2.7500 \\
\begin{array}{l}2.7200 \\
3.257 \\
3.22177\end{array}\end{array}$} & \multirow{3}{*}{ 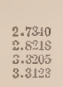 } & \multirow[b]{2}{*}{0.0136} & \multirow{5}{*}{ 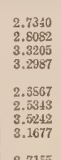 } & & & & & & \\
\hline & & & & & & & & 1.4995 & 0.0282 & $\begin{array}{l}2.28364 \\
3.3205 \\
\end{array}$ & $\begin{array}{l}3.6981 \\
3.6592 \\
3\end{array}$ & $\begin{array}{l}\text { 3.1.1866 } \\
3.310707 \\
\end{array}$ & $\{0.0150$ \\
\hline 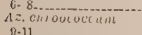 & \multirow{5}{*}{$\begin{array}{l}0 \\
0 \\
F \\
0 \\
F \\
F \\
0 \\
F \\
0\end{array}$} & \multirow{2}{*}{$\begin{array}{l}\text { Outs } \ldots \ldots \ldots \ldots . . . . . . \\
\text { Oats } \\
\text { Clove1 …...... }\end{array}$} & & & & & & \multirow[b]{2}{*}{2.7597} & \multirow[b]{2}{*}{0.0227} & 3.3597 & 3.6020 & 3.4603 & $0.17 \omega$ \\
\hline . & & & \multirow{2}{*}{ 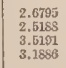 } & \multirow{2}{*}{ 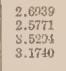 } & \multirow{2}{*}{ 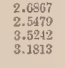 } & \multirow{2}{*}{$\begin{array}{l}-0.0369 \\
-0.0136\end{array}$} & & & & \multirow{2}{*}{\begin{tabular}{|l}
2.6567 \\
22.6560 \\
3.5522 \\
3.202020
\end{tabular}} & 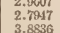 & 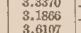 & \\
\hline нікім & & & & & & & & 1.0253 & 0.0343 & & & $\begin{array}{l}\text { S.1.60 } \\
3.4603 \\
\end{array}$ & 0.0225 \\
\hline$x_{0} \ldots$ & & $\begin{array}{l}\text { Oats } \\
\text { 0.15 }\end{array}$ & $\begin{array}{l}2.7227 \\
2.6353 \\
3\end{array}$ & $\begin{array}{l}2.7053 \\
2.5916 \\
3.41315\end{array}$ & $\begin{array}{l}2.7175 \\
2.6154 \\
3.333\end{array}$ & 0.0136 & $\begin{array}{l}2.7155 \\
2.5595 \\
3.2038\end{array}$ & $1.890 \overline{5}$ & 0.0225 & $\begin{array}{l}2.755 \\
2.0263 \\
3.3231\end{array}$ & \begin{tabular}{|l|}
2.0924 \\
2.8628 \\
3.6733
\end{tabular} & $\begin{array}{l}3.3570 \\
3.1866 \\
3.6607\end{array}$ & \\
\hline timin: & & Covet & 3.22223 & 3. 2051 & 3.2651 & 0.0136 & 3.2445 & 1.8310 & 0.0452 & $\begin{array}{l}3.2597 \\
3.259 \\
\end{array}$ & 3.6557 & 3.4603 & 0.1253 \\
\hline $8 . .$. & $\stackrel{F}{a}$ & $\begin{array}{l}\text { Oats - } \\
\text { otst : }\end{array}$ & $\begin{array}{l}2.8379 \\
2.6390 \\
3.377\end{array}$ & $\begin{array}{l}2.80191 \\
2.6938 \\
3.3133\end{array}$ & $\begin{array}{l}2,52355 \\
2.03930 \\
3,322515\end{array}$ & 0.0236 & \begin{tabular}{|l}
2.5295 \\
2.6500 \\
3.2505
\end{tabular} & 2.0178 & 0.0506 & $\begin{array}{l}2.8835 \\
2.737306 \\
3.2025\end{array}$ & \begin{tabular}{|l}
3.1115 \\
2.9963 \\
36591
\end{tabular} & $\begin{array}{l}3.3870 \\
3.1866 \\
8.8607\end{array}$ & \\
\hline 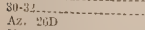 & & cores & 3.8070 & 3,4216 & 3.1143 & 0.0130 & $\begin{array}{l}3.4007 \\
.4007\end{array}$ & 3.1785 & 0.0022 & $\begin{array}{l}8.4630 \\
3.4638\end{array}$ & | 3.6522 & $\begin{array}{l}3.4603 \\
3.440\end{array}$ & 0.172 \\
\hline & $\mathrm{v}$ & $\begin{array}{l}\text { Oats } \\
\text { Outs } \\
\text { culse }\end{array}$ & $\begin{array}{l}2.7517 \\
2.8537 \\
3.543\end{array}$ & 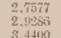 & $\begin{array}{l}2.75777 \\
2.8712 \\
3,49212\end{array}$ & 0.0136 & \begin{tabular}{|l|}
2.74577 \\
2.8776 \\
8.921
\end{tabular} & 2.2515 & 0.034 & \begin{tabular}{|l|}
2.7517 \\
2.0102 \\
3.4021
\end{tabular} & \begin{tabular}{|l}
3.0376 \\
3.1730 \\
3.8492
\end{tabular} & $\begin{array}{l}3.3 .370 \\
3.1566 \\
3.6106\end{array}$ & $0.5 \times$ \\
\hline $\begin{array}{l}38-40 \\
\text { iz. }\end{array}$ & $c$ & cilover & $\begin{array}{l}3.0456 \\
3.0567\end{array}$ & $\begin{array}{l}5.0450 \\
3\end{array}$ & 3.0613 & 0.0130 & \begin{tabular}{|l|l|} 
& 3.05121 \\
\end{tabular} & 2.2800 & $6.6+49$ & 3.0051 & 3.3374 & 3.4603 & \\
\hline & F & $\begin{array}{l}\text { Onts - } \\
\text { Oats - } \\
\text { Clowes }\end{array}$ & $\begin{array}{l}2,67501 \\
2.0112\end{array}$ & $\begin{array}{l}2.2025 \\
3.1555\end{array}$ & $\begin{array}{l}2.7015 \\
3.0003 \\
3.147 \\
\end{array}$ & 0.0136 & \begin{tabular}{|l}
2.7015 \\
3.0367 \\
3.46187
\end{tabular} & 1.0000 & 0.0032 & $\begin{array}{l}2.7015 \\
3.0609 \\
3.147\end{array}$ & $\begin{array}{l}2.8770 \\
3.3429 \\
3.9501\end{array}$ & $\begin{array}{l}3.3 .370 \\
3.1866 \\
3.3607\end{array}$ & 0.1868 \\
\hline Eii & & $\begin{array}{l}\text { Crove } \\
\text { clons }\end{array}$ & \begin{tabular}{|l|}
3.5059 \\
3.5059 \\
\end{tabular} & $\begin{array}{l}3.5059 \\
3.5059\end{array}$ & $\begin{array}{l}3.5019 \\
3.5609\end{array}$ & 0.0136 & 3.4733 & 1.8225 & 0.0472 & 3.5225 & 3.8613 & 3.46603 & 0.4010 \\
\hline$=$ & c & $\begin{array}{l}\text { Oate : } \\
\text { Onts } \\
\text { Clower }\end{array}$ & $\begin{array}{l}2.7227 \\
2.8283 \\
3.20077\end{array}$ & 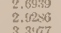 & 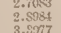 & 0.0133 & 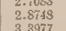 & 1.8625 & 0.0335 & \begin{tabular}{|l|}
$\begin{array}{l}2.7003 \\
2.0038 \\
: .0037\end{array}$ \\
\end{tabular} & 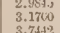 & $\begin{array}{l}\begin{array}{l}3.3370 \\
3.1566 \\
3.567\end{array} \\
\end{array}$ & \\
\hline 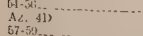 & & Clove & 3.3051 & 3.2353 & 3.8007 & 0.0136 & 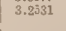 & 2.5103 & 0.0283 & 8.2959 & 3..595 & 8.4003 & 0.1322 \\
\hline & $\begin{array}{l}T \\
O \\
F\end{array}$ & $\begin{array}{l}\text { Dats } \\
\text { outs } \\
\text { Clor }\end{array}$ & 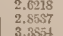 & $\begin{array}{l}2.6074 \\
2.755 \\
3.4112\end{array}$ & 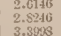 & 0.0136 & \begin{tabular}{|l}
2 \\
2.6 .61106 \\
3.3998 \\
3.3998
\end{tabular} & 3.0305 & 0.057 & $\begin{array}{l}2.2616 \\
2.8651 \\
2.3035\end{array}$ & 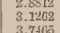 & 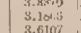 & \\
\hline a culturs & 0 & Chor & 3.1740 & 3.1740 & 3.1740 & 0.0136 & 3.1604 & 2.2090 & 0.0287 & 3.2031 & \begin{tabular}{|l}
3.4913 \\
\end{tabular} & 3.4.4003 & $\begin{array}{l}0.0310 \\
\end{array}$ \\
\hline$\cdots$ & $\mathrm{c}$ & $\begin{array}{l}\text { Ont } \\
\text { Ollor }\end{array}$ & 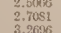 & 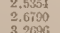 & 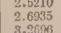 & 0.0136 & 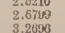 & 2.2315 & 0.0922 & $\begin{array}{l}2.7201 \\
2.77221 \\
3.3025\end{array}$ & 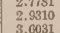 & $\begin{array}{l}3.3370 \\
3.1665 \\
3.156 .7\end{array}$ & - \\
\hline 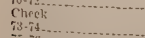 & $\mathrm{T}$ & $\mathrm{Clo}_{0}$ & $\begin{array}{l}0.4216 \\
3.460\end{array}$ & 3.2.158 & 3.8 & 0.0136 & 3.3716 & 1.6933 & 0.0375 & 3.4001 & 3.7159 & 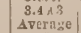 & 0.2556 \\
\hline & F & $\begin{array}{l}\text { Sot } \\
\text { Sot } \\
\text { Sot } \\
\text { sot }\end{array}$ & \begin{tabular}{|l|}
2.809 \\
2.7518 \\
2.96969
\end{tabular} & $\frac{2.5}{2.7}$ & $\mid \begin{array}{l}2.823 \\
2.751 \\
0,23\end{array}$ & 0.0136 & $\begin{array}{l}2.825 \\
3.73252 \\
\end{array}$ & 3.0903 & 0.0669 & $\begin{array}{l}2.2835 \\
2.7851 \\
2.751\end{array}$ & \begin{tabular}{|l}
3.115 \\
3.0 .577 \\
3.0593
\end{tabular} & $f$ & 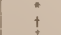 \\
\hline & 0 & No & 2.7935 & 2.7518 & 2.7736 & 0.0136 & 2.7600 & 1.0560 & 0.0257 & 2.7557 & 3.0364 & 11 & it \\
\hline
\end{tabular}

APPENDIX TABLE III.

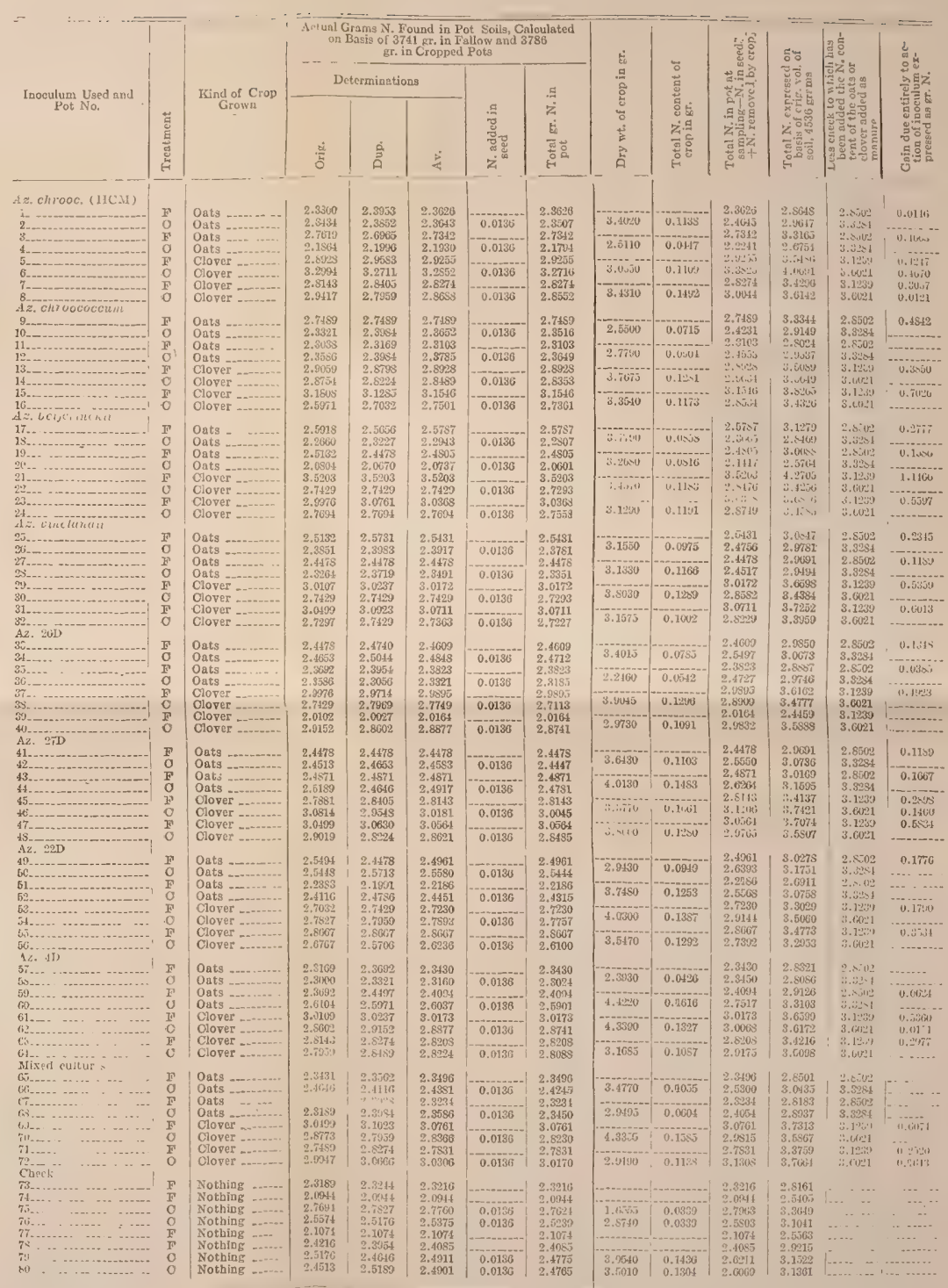

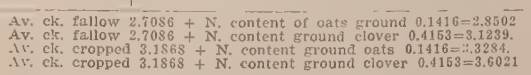





\section{BIBLIOGRAPHY}

1. ASHBY, S. F.

1907. Some observations on the assimilation of atmospheric nitrogen by a free-living organism-Azotobacter chroococcum of Beijerinck. Journ. Agr. Sci. 2:35.

2. BEIJERINCK, M. W.

1901. Nitrogen fixing bacteria. Centbl. f. Bakt. 2 Abt. 7:561.

3. BEIJERINCK, M. W.

1908. Fixation of nitrogen by pure culture of azotobacter; distribution of the organism. K. Akad. Wetensch. Amsterdam, Proc. Sect. Sci. 11:67.

1908. Abs. in Journ. Chem. Soc. 94:975.

4. BEIJERINCK, M. W. and VAN DELDEN, A. V.

1902. The assimilation of free nitrogen by bacteria. Centbl. f. Bakt. 2. Abt. 9:3.

5. BOLLEY, H. L.

1900. The duration of bacterial existence and trial environments. Centbl. f. Bakt. 2 Abt. 6:33.

6. BONAZZI, A.

1915. Cytological studies of Azotobacter chroococcum. Journ. Agr. Rsch. 4:225.

7. BOTTOMLEY, W. B.

1907. Cereals and bacteria. Country Life, 22:466.

\&. BOTTOMLEY, W. B.

1910. The fixation of nitrogen by free-living soil bacteria. Proc. Roy. Soc. Ser. B. 82:627.

1910. Abs, in Journ. Soc. Chem. Indus. 29:1171.

9. BOTTOMLEY, W. B. and HALL, A. D.

1909. Nitrogen-fixing bacteria and non-leguminous plants. Nature 82:218.

10. CHRISTENSEN, H. R.

1906. On the occurrence and distribution of Azotobacter chroococcum in different soils. Centbl. f. Bakt. 17:109, 161, 378.

11. CZAPLEWSKI, E.

1889. Bacteriological methods. Centbl, f. Bakt. Abt. 6:409.

12. DVORAK, J.

1912. Studies on nitrogen fixation in soil by micro-organisms. Zeitschr. $\mathfrak{e}$. d. Landw. Versuchswes in Oster. Jahrg. 15:1077.

1913. Abs. in Centbl. f. Bakt. 2 Abt, 37:106.

13. EHRENBERG, P.

1909. The bearing of carbon determinations upon nitrogen fixation in soils. Fühling's Landw. 2tg. 58:663.

14. FISCHER, H.

1905. Contribution to the knowledge of the life conditions of nitrogen-collecting bacteria. Centbl. f. Bakt. 2 Abt. 14:33, 781.

15. FISCHER, H.

1905. Nitrogen fixing bacteria. Journ. Landw. 58:61.

36. FISCHER, H.

1905. Contribution to the knowledge of the life conditions of nitrogen-collecting bacteria. Journ. Landw. 53:289.

17. FRENDENREICH, E. DE

1903. Assimilation of atmospheric nitrogen by bacteria. Centbl. f. Bakt. 2 Abt. 10:514. 
18. GERLACH, M. and VOGEL, I.

1902. Nitrogen-gathering bacteria. Centbl. f. Bakt. 2 Abt. 8:669; 9:816;9:881.

19. GERLACH, M., and VOGEL, I.

1903. Further studies on nitrogen gathering bacteria. Centbl. f. Bakt. 2 Abt. 10:636.

20. GREAVES, J. E., and ANDERSON, H. P.

1914. The influence of arsenic upon the nitrogen fixing powers of the soil. Centbl. f. Bakt. 2 Abt. 42:244.

21. HEADDEN, W. P.

1910. The fixation of nitrogen in some Colorado soils. Bull. Colo. Agr. Exp. Sta. 155.

1911. Bull. Colo. Agr. Exp. Sta. 178.

1913. Bull. Colo. Agr. Exp. Sta. 186.

22. HEINZE, B.

1906. Some contributions to the microbiology of soils. Centbl. 1 . Bakt. 2 Abt. 16:640.

23. HEINZE, B.

1906. Concerning nitrogen fixation by lower organisms. Landw. Jahr, 35: 889.

24. HOFFMAN, C.

1913. The protein and phosphorus content of azotobacter cells. Centbl. f. Bakt. 2 Abt. 36:474.

25. HOFFMAN, C., and HAMMER, B. W.

1911. Some factors concerned in the fixation of nitrogen by azotobacter. Res. Bull. Wisc. Agr. Exp. Sta. 12.

26. JACOBITZ, E.

1901. The assimilation of free atmospheric nitrogen. Centb. f. Bakt. 2 Abt. $7: 783,833,876$.

27. JONES, D. H.

1913. A morphological and cultural study of some azotobacter. Centbl. f. Bakt. 2 Abt. 38:14.

28. KASERER, H.

1910. On the mineral needs of azotobacter. Ber. d. Deutsch. Bot. Gesell. 28:208.

29. KELLERMAN, K. F., and SMITH, N. R.

1914. The absence of nitrate formation in cultures of azotobacter. Centbl. f. Bakt. 2 Abt. $\mathbf{4 0 : 4 7 9 .}$

?. KOCH, A.

1910. On nitrogen fixation in soils with cellulose as a source of energy. Centbl. f. Bakt. 2 Abt. $\mathbf{2 7}: 1$.

1907. Mitt. Deut. Landw. Gesell. 22:117.

1909. Journ. Landw. 5\%:269.

31. KOCH, A.; and SEYDEL, S.

1911. The utilization of cellubiose as a source of energy in nitrogen fixation through bacteria. Centbl. f. Bakt. 31:567.

3\%. KOBER, P., and SUGIURA, S.

1913. A micro-chemical method for the determination of alpha and beta amino acids and certain derivatives in proteolysis, blood and urine. Journ. Amer. Chem. Soc. 35:1546.

33. KRAINSKY, A.

1908. Azotobacter chroococcum and its action in the soil. Centbl. f. Bakt. 2 Abt. $20: 725$.

1910. Centbl, f. Bakt. 2 Abt. $23: 231$.

34. KUHN, J.

1901. The assimilation of free nitrogen by soil bacteria without symbiosis with leguminous plants. F'ühling's Landw. Ztg. 50:2. 
25. LIPMAN, J. G.

1904. Soil bacteriological studies. Rpt. N. J. Agr. Exper. Sta. $1904: 237$.

36. LIPMAN, J. G.

1903. Nitrogen-fixing bacteria. Doctor's thesis, Cornell University.

37. LIPMAN, J. G.

1903. Experiments on the transformation and fixation of nitrogen by bacteria. Rpt. N. J. Agr. Expt. Sta. 1903:247.

88. LIPMAN, J. G.

1904. Soil bacteriological studies. Rpt. N. J. Agr. Exp. Sta. 1904: 263.

39. LIPMAN, J. G.

1902. Nitrogen-fixing bacteria. Pop. Sc. Monthly. 62:97.

1903. Rpt. N. J. Agr. Exp. Sta, 1903:217.

1904. Bull. Bur. Chem. 81:146.

40. LIPMAN, J. G. and BROWN, P. E.

1911. Laboratory guide in soil bacteriology.

41. LIPMAN, J. G., and BROWN, P. E.

1907. Report of the soil chemist and bacteriologist. Rpt. N. J. Agr. Exp. Sta. 1907:141.

42. LIPMAN, C. B., and BURgESS, P. S,

1915. Studies on nitrogen fixation and azotobacter forms in soils in foreign countries. Centbl. f. Bakt. 2 Abt. $4: 481$.

43. LöHNIS, F'.

1909. The importance of nitrogen fixation in cultivated soil. Fühling's Landw. Ztg. 58:425.

44. LÖHNIS, F., and HANZAWA, J.

1914. The classification of azotobacter. Centbl. f. Bakt. 12:1.

45. LöHNIS, F., and PILLAI, N. K.

1908. Nitrogen-fixing bacteria. Centbl. f. Bakt. 2 Abt. 20:781.

46. LöHNIS, F., and PILLAI, N. K.

1907 Nitrogen-fixing bacteria. Centbl. f. Bakt. 2 Abt. 19:87.

47. LöHNIS, F., and SMITH, N. R.

1916. Life cycles of bacteria. Journ. Agr. Rsch. 6:675.

48. LÖHNIS, F., and WESTERMANN, T.

1908. Nitrogen-fixing bacteria. Centbl. f. Bakt. 2 Abt. 22:234.

49. LUTZ, L.

1905. The morphology and biology of nitrogen-assimilating organisms. Centbl. f. Bakt. 15:477.

50. MULVANIA, M.

1915. Observations on azotobacter. Science, N. S. 42:463.

51. OMELIANSKY, W. L. and SSEWEROWA, O. P.

1911. Pigment formation in cultures of Azotobacter chroococcum Centbl. f. Bakt. 2 Abt. 29:643.

52. PETERSON, E. G., and MOHR, E.

1913. Non symbiotic nitrogen fixation by organisms in Utah soils. Centb. f. Bakt. 2 Abt. 38:494.

53. POTTER, R S., and SNYDER, R. S.

1915. Determination of amino acids and nitrates in soils. Res. Bull. Ia. Agr. Exp. Sta. 24.

54. PRAZMOWSKI, A.

1912. Natural history, morphology and cytology of Azotobacter chroococcum. Centbl. f. Bakt. 2 Abt. 33:292.

55. PRINGSHEIM, $\mathrm{H}$.

1907. On the adaptability of different sources of energy to assimulation of atmospheric nitrogen and the distribution of nitrogen-fixing bacteria in the soil. Centbl. f, Bakt, 2 Abt. 20:248,

1908. Centbl. f. Bakt. 2 Abt, 26:222. 
56. PRINGSHEIM, H.

1914. Nitrogen assimilation in the presence of nitrates. Centbl. f. Bakt. 2 Abt. $40: 21$.

57. REMY, T.

1909. Investigations on the process of nitrogen assimilation in its relation to the soil climate. Centbl. f. Bakt. 2 Abt. 22:561.

58. REMY, T., and ROSING, G.

1911. The biological stimulation of natural humus. Centbl. f. Bakt. 2 Abt. 30:349.

59. ROSING, G.

1912. Results of the investigations on nitrogen fixation by Azotobacter chroococcum. Centbl. f. Bakt. 2 Abt. 33:292; 618.

60. STOKLASSA, J.

1908. Contribution to the knowledge of the chemical processes involved in the assimilation of free nitrogen by azotobacter and radiobacter. Centbl. f. Bakt. 2 Abt. 21:484.

61. STRANAK, J.

1909. The assimilation of atmospheric nitrogen by soil microorganisms. Centbl. f. Bakt. 2 Abt. 25:320.

62. THIELE, R.

1906. The utilization of atmospheric nitrogen by micro-organisms. Landw. Vers. Sta. 63:161.

63. VAGLER, P. 3

1909. The fixation of atmospheric nitrogen. Centbl. f. Bakt. 2 Abt. 22:452.

64. VOGEL, J.

1912. Potash requirements by the nitrogen bacteria. Centbl. f. Bakt. 2 Abt. 32: 411.

65. VOGEL, J.

1903. Some recent investigations in nitrogen assimilation by bacterla without symbiosis. Fühling's Land Ztg. 52:178.

1903. Reference Exp. Sta. Rec. 14:1048.

66. VORHEES, E. B., and LIPMAN, J. G.

1905. Experiments on the accumulation and utilization of atmospheric nitrogen in the soil. Bull. N. J. Agr. Exp. Sta. 180.

67. WILFARTH, H., and WIMMER, G .

1907. The influence of mineral fertilization on the nitrogen fixaation by lower organisms in the soil. Landsw. Vers. Sta. 67:27.

68. WARMBOLD, H.

1906. Investigations on the biology of the nitrogen fixing bacteria. Landw. Jahs. 35, No. 1-2; 1., 35, No. 4-6; 63. 
- 
LIBRARY OF CONGRESS

00027566352 